\title{
Population Structure Among and Within lowa, Missouri, Ohio, and South Dakota Populations of Phytophthora sojae
}

S. Stewart and A. E. Robertson, Department Plant Pathology and Microbiology, Iowa State University, Ames 50011; D. Wickramasinghe, Department of Plant Pathology, The Ohio State University, Ohio Agricultural Research and Development Center (OARDC), Wooster 44691; M. A. Draper, Plant Science Department, South Dakota State University, Brookings 57007-1090; and A. Michel, Department of Entomology, and A. E. Dorrance, Department of Plant Pathology, The Ohio State University, OARDC

\begin{abstract}
Stewart, S., Robertson, A. E., Wickramasinghe, D., Draper, M. A., Michel, A., and Dorrance, A. E. 2016. Population structure among and within Iowa, Missouri, Ohio, and South Dakota populations of Phytophthora sojae. Plant Dis. 100:367-379.

Phytophthora root and stem rot, caused by Phytophthora sojae, is an economically important disease of soybean throughout the Midwestern United States. This disease has been successfully managed with resistance (Rps) genes; however, pathogen populations throughout the Midwest have developed virulence to many Rps genes, including those that have not been deployed. To gain a better understanding of the processes that influence $P$. sojae evolution, the population genetic structure was compared among populations using one isolate collected from 17, 33, and 20 fields in Iowa, Ohio, and South Dakota, respectively, as well as multiple isolates from individual fields in Iowa, Ohio, and Missouri. Genotypic diversity was measured using 21 polymorphic microsatellite (simple-sequence repeat) markers. and pathotype diversity using 15 soybean differentials. For all but three of the populations with low sample size, there was a high level

of pathotype diversity and a low to moderate level of genotypic diversity among the populations for both comparisons between states and withinfield variation. None of the Rps-gene differentials were resistant to all of the isolates. There were 103 unique multilocus genotypes identified in this study and only 2 were identified from the same field. Although no clones were identified in more than one field, pairwise $F_{\mathrm{ST}}$ indicated that some gene flow within neighboring fields does occur but not across the region, including fields from neighboring states. These results suggest that there is a strong probability that each state may have their own or several regional populations, as well as provide further evidence of high diversity within this homothallic pathogen which may be due, in part, to limited gene flow, mutation, or outcrossing, and this likely affects the success of deployment of resistance.
\end{abstract}

The longevity of single dominant resistance $(R)$ genes is very dependent on the genetics and diversity of the targeted pathogen population. Phytophthora sojae Kaufm. \& Gerd. (syn. Phytophthora megasperma f. sp. glycinea T. L. Kuan \& Erwin) is an oomycete pathogen which causes Phytophthora root and stem rot, which has been managed with single dominant $R$ genes (Rps genes) for the past 50 years (Grau et al. 2004; Schmitthenner 1985). This pathogen can infect soybean at all growth stages and symptoms can include pre- and postemergence damping-off, root rot, and stem lesions on susceptible cultivars. Yield reduction due to Phytophthora root and stem rot has been reported from many of the top soybean-producing countries, including Argentina, Canada, China, Japan, and the United States (Dorrance and Grünwald 2009). During 1996 to 2007, this disease ranked second or third among the most important diseases in the United States affecting yield, following soybean cyst nematode (Wrather and Koenning 2009).

Seventeen Rps genes in soybean have been identified to date, which confer resistance to $P$. sojae (Grau et al. 2004; Lin et al. 2013; Sun et al. 2011; Zhang et al. 2013). Several genes such as Rps1a, Rps1c, and $R p s 1 \mathrm{k}$ have been incorporated into commercial cultivars (Grau et al. 2004); however, as in many other host-pathogen systems which are governed by a gene-for-gene system (Flor 1955), the pathogen adapts to the specific Rps gene in soybean. Thus, the effectiveness of Rps genes has been eroded progressively as new races and pathotypes of the pathogen have emerged. Changes in virulence have occurred

\section{Corresponding author: A. E. Dorrance; E-mail: dorrance.1@ @su.edu}

*The $\boldsymbol{e}$-Xtra logo stands for "electronic extra" and indicates that one supplementary table is published online.

Accepted for publication 3 July 2015

http://dx.doi.org/10.1094/PDIS-04-15-0437-RE

(C) 2016 The American Phytopathological Society throughout the United States at a fairly rapid pace for a soilborne pathogen, and durability of Rps effectiveness in the field has been estimated to be 8 to 20 years (Dorrance et al. 2003; Grau et al. 2004). A better understanding of the genetic diversity within $P$. sojae and its relationship to pathotype diversity would improve our ability to incorporate the most effective and durable resistance into soybean cultivars.

To understand the processes that lead to the failure of an $R$ gene to a specific pathogen population, the mechanisms that govern a pathogen's evolution should be well understood (McDonald and Linde 2002b). McDonald and Linde (2002a,b) proposed five evolutionary forces that may shape the evolutionary potential of a pathogen, and knowledge of these can be used to predict the "risk" of overcoming resistance. Pathogens that pose the greatest risk of overcoming $R$ genes have (i) mixed reproduction systems, (ii) a high gene flow, (iii) large effective population sizes, (iv) high mutation rates, and (v) strong selection posed by genetically uniform crops. In their analysis, $P$. sojae was proposed to be a medium-risk pathogen due to its (i) potential to outcross (as determined under laboratory conditions) (Whisson et al. 1994), (ii) the presence of a mixed reproduction system which ensures new combinations of alleles during sexual cycle that are increased to high frequencies through asexual cycles, (iii) limited gene flow due to its soilborne nature, (iv) low effective population size because it is monocyclic, and (v) low mutation rates coupled with efficient directional selection posed by deployed Rps genes.

Pathotypes and races of $P$. sojae are monitored through virulence tests using a soybean differential set consisting of 8 to 15 soybean genotypes, each of which has one Rps gene and a universal susceptible (Dorrance et al. 2004). Fifty-five races of $P$. sojae were officially described based on eight differentials (Rps 1a, Rps 1b, Rps 1c, Rps $1 \mathrm{~d}$, $R p s 1 \mathrm{k}, R p s 3 \mathrm{a}, R p s 6$, and Rps7) prior to 2000 (Grau et al. 2004). Due to increasing pathogen diversity, assigning race numbers became cumbersome and, currently, a direct virulence formula (indicating the Rps gene in soybean that the isolate is able to infect) is used to designate pathotype. Pathotype diversity of $P$. sojae in Ohio and Iowa has 
increased since race 1 (virulence to Rps 7) of the pathogen was first reported in each state (Dorrance et al. 2003; Niu 2004; Schmitthenner et al. 1994; Yang et al. 1996). In the most recent surveys, based on a standard set of eight differentials, there were 72 pathotypes identified from 82 fields in Ohio (Dorrance et al. 2003) and 17 pathotypes identified from 99 fields in Iowa (Niu 2004). While using 13 differentials, more than 50 pathotypes were identified in two intensively sampled fields in Ohio (Dorrance et al. 2003), and 12 and 19 pathotypes were identified from soil samples collected in two separate fields in Iowa (Robertson et al. 2009). These results suggest a very high level of genetic variation with respect to virulence in these naturally occurring populations both within and across a geographic region.

Like many soilborne pathogens, $P$. sojae has limited means of dispersal and, thus, gene flow among populations is thought to be limited, especially when compared with organisms with long-distance aerial dispersal whose gene flow spans continental and global scales (Barrett et al. 2008). P. sojae is also homothallic (selfing) and is expected to have a high degree of clonality, with a few genotypes present at high frequencies. Sexually outcrossing reproducing organisms often have a high degree of genotypic diversity (Chen and McDonald 1995). This aspect of limited dispersal and the homothallic nature are in direct contrast to the pathotype diversity within $P$. sojae that has been identified previously in the North-Central region of the United States (Abney et al. 1997; Dorrance et al. 2003; Kaitany et al. 2001; Kurle and El Araby 2001; Meng et al. 1999; Niu 2004; Robertson et al. 2009).

Genotypic diversity among the U.S. populations of $P$. sojae has been studied previously, although each study focused on a very limited number of isolates (Drenth et al. 1996; Förster et al. 1994; Meng et al. 1999). In one of the first studies to look at mechanisms that contribute to genetic variation in P. sojae, Förster et al. (1994) examined a collection of 48 isolates, of which 2 to 9 isolates were recovered from soybean in seven states in the United States (Arkansas, Indiana, Illinois, Ohio, Mississippi, Virginia, and Wisconsin); New South Wales and Queensland, Australia; Ontario, Canada; and Japan, with 46 nuclear restriction fragment length polymorphism (RFLP) markers. The isolates were selected based on the race and could be divided into four distinct groups based on allele specificity. One group of nine isolates had nearly identical RFLP and included isolates recovered from Australia, Ohio, Mississippi, and Ontario, while the remaining isolates had greater genetic variation. Interestingly, there were three Ohio isolates included in the study, of which two were in one clonal group but represented different races and the third was in a distinct group linked with isolates originating from Japan. There were also eight isolates from Indiana in the Förster et al. (1994) study, of which two were clones in group I, one in group II, two in group III, and three in group IV. Förster et al. (1994) proposed that rare outcrosses between representatives of these four groups may contribute to the origin of new physiological races in addition to clonal evolution. Similarly, four groups were detected with random amplified polymorphic DNA (RAPD) markers in a study of a different set of 55 P. sojae isolates collected from soil or diseased plants in Illinois, Indiana, Iowa, and Minnesota during 1994 to 1995 (Meng et al. 1999). There were clones identified among this collection; specifically, 14 isolates had the same RAPD banding pattern regardless of geographic origin and included pathotypes representing race 1,8 , and 13 (vir $R p s 7 ; 1 \mathrm{a}, 1 \mathrm{~d}, 6$, and 7; and 6 and 7, respectively). In this study, 2 of the 55 isolates of $P$. sojae that originated from Ohio were in groups III and IV, while isolates from Iowa were all in groups I and II (Meng et al. 1999).

In all, 21 polymorphic microsatellites were developed from sequence data of $P$. sojae race 2 (Dorrance and Grünwald 2009; Tyler et al. 2006), and 53 alleles were identified among 33 isolates of $P$. sojae from Ohio in a preliminary study, with an average of 2.5 alleles per locus (Dorrance and Grünwald 2009). All alleles deviated significantly from Hardy-Weinberg equilibrium (HWE) and the observed heterozygosity was low, as expected for a homothallic soilborne species, with an overall mean of 0.015 (Dorrance and Grünwald 2009). Based on these data, Dorrance and Grünwald (2009) posed several questions. (i) How often is outcrossing occurring in fields and does it contribute to the overall changes in the virulence as well as the accumulation of virulence to numerous Rps genes among these $P$. sojae populations? (ii) Are the same loci in significant disequilibria across all populations? (iii) Are the same mechanisms that drive diversity in place across all regions?

The genetic diversity and population structure of $P$. sojae at field, state, and regional levels in the North-Central region of the United States could improve our understanding of Phytophthora root and stem rot of soybean by elucidating the mechanisms that drive genetic changes in the pathogen and, consequently, lead to improved management tactics, specifically those related to the deployment of resistant cultivars. A study evaluating the diversity of $P$. sojae at these levels requires a much deeper sampling of a larger number of isolates from intensively sampled fields within a region as well as comparisons across several geographically distinct locations. We hypothesized that the genetic structure within each population of $P$. sojae would be highly diverse, as has been reported for pathotype diversity; there would be additional evidence of outcrossing; and the same loci would have similar rates of disequilibrium. Therefore, the objectives of this study were to compare the population structure of $P$. sojae isolates from (i) one isolate per field in Iowa, Ohio, and South Dakota; (ii) within individual fields from Iowa, Ohio and Missouri; (iii) within the same plant to determine whether outcrossing is occurring in planta and contributing to changes in pathotype; and (iv) with previous reports (Dorrance and Grünwald 2009; Förster et al. 1989, 1994; Meng et al. 1999). Thirty-three isolates were used in the original assessment of simple-sequence repeats (SSR) as an efficient molecular marker system that is transferable among labs (Dorrance and Grünwald 2009).

\section{Materials and Methods}

$\boldsymbol{P}$. sojae isolates. More than 200 isolates of $P$. sojae were evaluated in this study, many of which were collected from the same fields in four states: Iowa, Ohio, Missouri, and South Dakota (Fig. 1). Among these were 10 isolates from a separate field in Iowa, collected during 2001 (Niu 2004), that had been stored in water blanks and were still viable. There were an additional 59 isolates from seven locations in Iowa recovered from symptomatic plants or baited from soil during 2008 to 2010. In total, 110 isolates were recovered from plants or baited from soil from 36 fields in 24 counties in Ohio between 1997 and 2010. For two fields in Ohio, soil samples for baiting were collected on a grid and pathotype was previously reported (Sandusky, $\mathrm{OH}$ and Wood, $\mathrm{OH}$; Dorrance et al. 2003). Twenty isolates each recovered from one plant per field in South Dakota during 2002 to 2004 were provided by M. Draper (South Dakota State University). The 20 isolates of $P$. sojae from Missouri were baited from separate soil cores sampled in a 7.5-m grid in 2008 from one field at the Lee Farm at the Delta Research Station in Portageville. All of the fields from Iowa and four additional fields from Ohio were arbitrarily sampled by walking and collecting plants with symptomatic stem rot samples, ensuring that no plant was collected within $3 \mathrm{~m}$ of another plant. Isolates from Missouri, Ohio, and South Dakota were maintained in liquid nitrogen or on $\mathrm{V} 8$ agar slants at $15^{\circ} \mathrm{C}$ (Dorrance et al. 2008). Isolates from Iowa were maintained on half-strength V8 juice agar blocks in sterile, distilled water at room temperature.

For the isolates baited from soil, seedlings of 'Sloan' (no Rps genes) were used as bait. Briefly, soil samples were air dried, ground, and placed into $15.2-\mathrm{cm}$. pots. Soils were flooded for $24 \mathrm{~h}$, allowed to drain for approximately $24 \mathrm{~h}$, and placed in plastic bags for 2 weeks to allow oospores to germinate. Seed were placed on the soil and covered with vermiculite and soils were flooded again for $24 \mathrm{~h} 3$ days after placement. Symptomatic seedlings were collected 5 to 7 days after flooding and washed to remove soil, and lesions were placed onto diluted V8 juice agar amended with pentachloronitrobenzene, benomyl, neomycin sulfate, iprodione, and chloramphenicol (PBNIC) (Dorrance et al. 2008) medium and the medium flipped. For soybean plants collected directly from the field, the stems were thoroughly washed, the surface was disinfested with $5 \% \mathrm{NaOCl}$ solution, tissue was cut from the margin of healthy and symptomatic tissue and placed on PBNIC medium, and the medium flipped to limit bacterial growth (Dorrance et al. 2008). Isolates of $P$. sojae were confirmed by their growth pattern on PBNIC, failure to grow on full-strength potato 
dextrose agar, morphology of oospores on lima bean agar, and morphology of sporangia developed in washes of ChenZentmeyers' salt solution (Schmitthenner and Bhat 1994). A subset of isolates was further confirmed through analysis of the sequence amplified from the internal transcribed spacer (ITS) region of ribosomal DNA with universal forward ITS1 and reverse ITS4 primers (White et al. 1990).

Purification and storage of isolates. Isolates were purified using either monozoospores or hyphal tip culture. $P$. sojae does not form sporangia or zoospores readily in culture. For sporangia formation, mycelium from the perimeter of 1- to 3-day-old cultures was transferred to a petri dish with $15 \mathrm{ml}$ of sterile lima bean broth (LBB) ( $50 \mathrm{~g}$ of frozen lima bean in 1,000 $\mathrm{ml}$ of distilled water). After 48 to $72 \mathrm{~h}$ at room temperature and a 12-h light cycle, the LBB was decanted and replaced with Chen-Zentmeyers' salt wash solution $\left(0.01 \mathrm{M} \mathrm{Ca}^{2} \mathrm{NO}_{3}\right]_{2} \cdot 4 \mathrm{H}_{2} \mathrm{O}, 0.004 \mathrm{M} \mathrm{MgSO}_{4} \cdot 7 \mathrm{H}_{2} \mathrm{O}, 0.005 \mathrm{M} \mathrm{KNO}_{3}$, and $\mathrm{FeSO}_{4} \cdot 7 \mathrm{H}_{2} \mathrm{O}$ at $0.02 \mathrm{mg} /$ liter; $\mathrm{pH}$ 7.0) (Schmitthenner and Bhat 1994). After $15 \mathrm{~min}$, the salt solution was decanted and replaced with new salt solution, followed by a third wash with sterile water. Depending on the isolate, sporangia and zoospores formed after 5 to $12 \mathrm{~h}$ (Schmitthenner and Bhat 1994). Monozoosporic isolates were obtained by dispensing $200 \mu \mathrm{l}$ of the zoospore suspension from the salt wash onto water agar plates and transferring single germinated zoospores to dilute V8 medium under a stereo microscope after $24 \mathrm{~h}$. Hyphal tip cultures were also made using a stereomicroscope by transferring a single hyphal tip from each mass isolate onto a new dilute V8 agar plate. Purified isolates of $P$. sojae were stored in sterile distilled water at room temperature (Iowa) or on dilute V8 slants at $15^{\circ} \mathrm{C}$ (Missouri, Ohio, and South Dakota) until further use. Isolates were removed from storage and transferred directly to plates containing lima bean agar.

Pathotype characterization. Pathotypes of $P$. sojae isolates were determined using the hypocotyl inoculation technique on a set of 15 differential genotypes (Dorrance et al. 2008), with each differential having only one specific Rps gene. The differentials used in this study were L88-8470 (Rps1a, Mukden source) or Harlon (Rps1a, Blackhawk source), L77-1863 or Harosoy 13XX (Rps1b, Sanga source), Williams 79 (Rps1c), L99-3312 or PI 103091 (Rps1d), Williams 82 (Rps1k), L82-1449 or L76-1988 (Rps2, CNS source), L83-570 (Rps3a), L91-8347 or PRX-146-36 (Rps3b), L92-7857 or PRX-145-48 (Rps3c), L85-2352 (Rps4), L85-3059 (Rps5), Altona or L89-1581 or Harosoy 62XX (Rps6), L93-3258 or Harosoy (Rps7), PI 399073 (Rps8), and Williams (susceptible). Seed of each of the differentials has been maintained at The Ohio State University (OSU), Ohio Agricultural Research and Development Center in Wooster.

Soybean seed were grown on pasteurized potting mix (1:1:1 mixture of soil [Clarion Webster loam], sand, and vermiculite [Iowa State University]] or course vermiculite (OSU) in trays in the greenhouse. Ten 7-day-old seedlings of each differential were inoculated by making an incision in the hypocotyl with a syringe filled with a mycelial slurry of a 7- to 10-day-old culture of each isolate and placing approximately 0.2 to $0.4 \mathrm{ml}$ of slurry into the slit (Dorrance et al. 2008). A plastic covering was placed over the tray for 12 to $16 \mathrm{~h}$ to prevent the inoculum from drying. At 7 to 10 days after inoculation, the seedlings were evaluated. Plants that developed brown expanding lesions were classified as susceptible, while resistant plants developed a hypersensitive reaction (slight necrotic lesion around the wound). The differential was considered susceptible when at least 7 of the 10 seedlings developed an expanding necrotic lesion, indicating that this genotype was susceptible. The test was repeated at least twice for each isolate.

DNA extraction. Genomic DNA was extracted from mycelium using either a modification of the cetyltrimethylammonium bromide (CTAB) procedure (Dorrance et al. 1999) or a rapid extraction protocol (Zelaya-Molina et al. 2011). For the modified CTAB procedure, 8 to 10 square pieces $\left(5 \mathrm{~mm}^{2}\right)$ of $P$. sojae grown on diluted V8 agar were transferred to $250-\mathrm{ml}$ flasks containing $50 \mathrm{ml}$ of V8 broth ( $40 \mathrm{ml}$ of V8 juice, $0.6 \mathrm{~g}$ of $\mathrm{CaCO}_{3}, 0.2 \mathrm{~g}$ of Bacto yeast extract, $1 \mathrm{~g}$ of sucrose, and $0.01 \mathrm{~g}$ of cholesterol in $1,000 \mathrm{ml}$ of distilled water). Flasks were placed on shaker at 100 to $120 \mathrm{rpm}$ at room temperature for 4 to 7 days. Mycelium was harvested by vacuum aspiration through number 1 filter paper, frozen with liquid nitrogen, and ground using a sterile mortar and pestle. The dried powder mycelium was placed in a plastic 50 - $\mathrm{ml}$ centrifuge tube with $10 \mathrm{ml}$ of extraction buffer $(0.35 \mathrm{M}$ sorbitol, 0.1 M Tris, 0.0064 M EDTA, [pH 7.5], and 0.017 M sodium bisulfate) and vortexed. Lysis buffer $(10 \mathrm{ml}$ of $0.2 \mathrm{M}$ Tris, $0.064 \mathrm{M}$ EDTA [pH 7.5], $2.0 \mathrm{M} \mathrm{NaCl}, 2 \% \mathrm{CTAB}$, and $60 \mu \mathrm{l}$ of $5 \%$ sarkosyl [5 g of N-lauryl sarcosine per $100 \mathrm{ml}$ of $\left.\mathrm{H}_{2} \mathrm{O}\right]$ ) was added to the tubes, which were vortexed, then incubated at $-80^{\circ} \mathrm{C}$ for $15 \mathrm{~min}$, followed by $65^{\circ} \mathrm{C}$ for $15 \mathrm{~min}$. This step was repeated twice, with the final incubation at $65^{\circ} \mathrm{C}$ lasting $45 \mathrm{~min}$. One volume of phenol/chloroform/isoamyl alcohol $(25: 24: 1)$ was added to each tube and mixed gently, and then the tubes were centrifuged for $10 \mathrm{~min}$ at 2,000 rpm. The aqueous phase in the tube was transferred to a new tube and then one volume of chloroform/isoamyl alcohol (24:1) was added, followed by centrifugation and transfer to a new tube. DNA was precipitated by the addition of one volume of cold isopropanol and incubation at $-20^{\circ} \mathrm{C}$ overnight. Following centrifugation, the supernatant was discarded and the pellets were dried at room temperature, then resuspended in $200 \mu \mathrm{l}$ of Tris-EDTA (TE; $10 \mathrm{mM}$ Tris- $\mathrm{HCl}$ and $0.1 \mathrm{mM}$ EDTA, $\mathrm{pH} \mathrm{8.0)}$ ). Pancreatic RNase A $(2 \mu \mathrm{l}$ at $0.01 \mu \mathrm{g} / \mu \mathrm{l})$ was added to the DNA solution, which was incubated at $37^{\circ} \mathrm{C}$ for an hour; then, the solution was transferred to a $1.5-\mathrm{ml}$ tube and the alcohol washes were repeated.
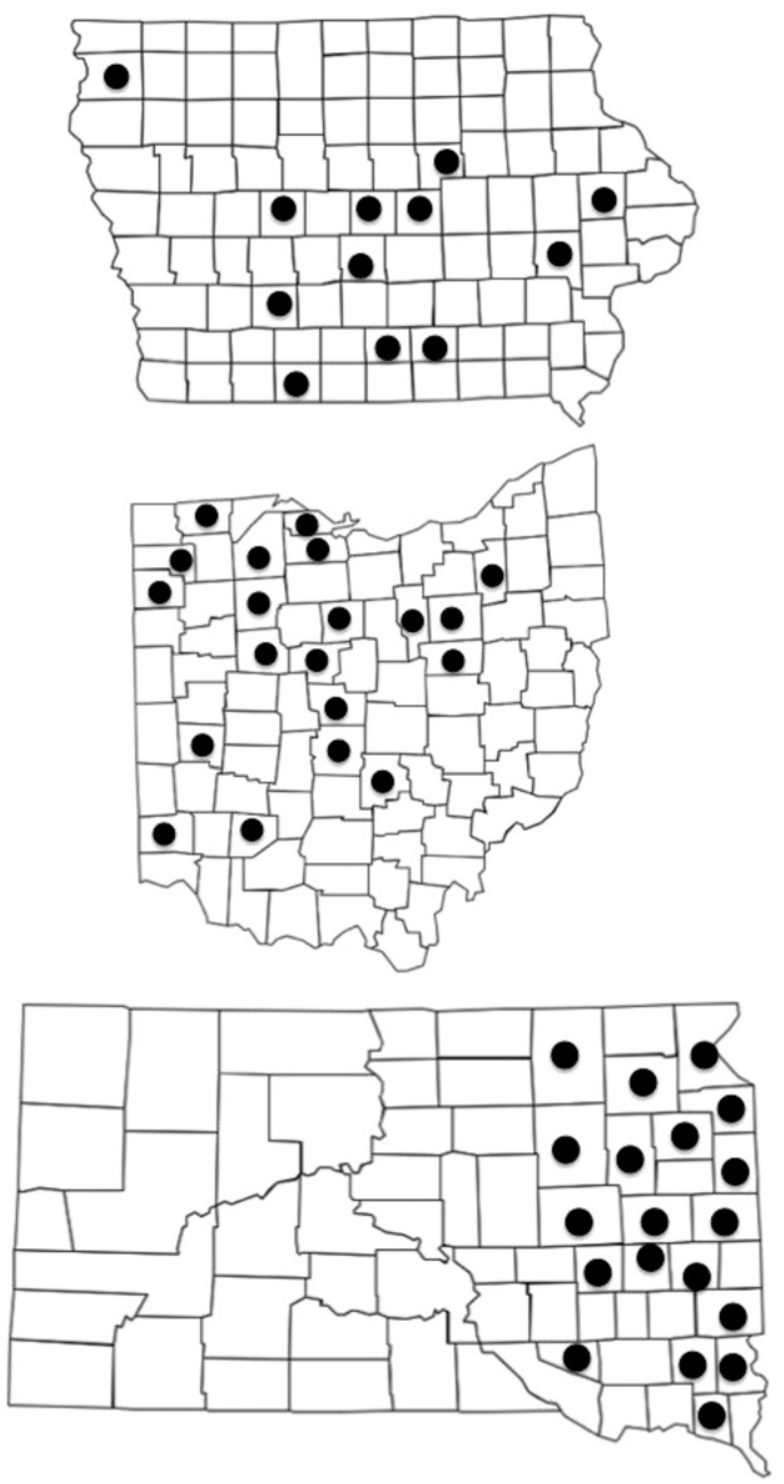

Fig. 1. Location of fields that were sampled for Phytophthora sojae to assess genetic diversity in lowa (top), Ohio (middle), and South Dakota (bottom). 
After the isopropanol was poured off, the pellets were washed in buffer (76\% ethanol and $0.8 \mathrm{M} \mathrm{NaOAc}, \mathrm{pH} 7.0)$ and rinsed (76\% ethanol and $0.026 \mathrm{M} \mathrm{NH}_{4} \mathrm{OAc}$ ). The rapid DNA extraction protocol was much simpler and yielded suitable quality DNA (Zelaya-Molina et al. 2011). DNA was then resuspended in TE and its concentration measured using a NanoDrop ND-1000 Spectrophotometer. DNA was extracted from all isolates as soon as they were purified. Concentrations were adjusted to $100 \mathrm{ng} / \mu \mathrm{l}$ and stored at $-20^{\circ} \mathrm{C}$ for SSR analysis.

Molecular genotypes. In total, 21 SSR primer pairs (Dorrance and Grünwald 2009; Schena et al. 2008; Stewart et al. 2011) were used to amplify these molecular loci. Of the 21 primer pairs, 13 (PS06, PS17, PS18, PS19, PS20, PS25, PS27, PS30, PS36, PS37, PS38, S64/65, and $568 / 69$ ) were analyzed on a $4 \%$ high-density agarose (Amresco) gel following amplification. The remaining eight SSR (PS01, PS05,
PS10, PS12, PS16, PS24, PS29, and PS33) (Dorrance and Grünwald 2009), which were previously identified as having the greater number of alleles per locus (Stewart et al. 2011), were analyzed using either the Applied Biosystems 3730 Genetic Analyzer (ABI) or CEQ 8000 Genetic Analyzer system (CEQ; Beckmann Coulter) capillary electrophoresis methods. The DNA sizing ladder was $100 \mathrm{bp}$ for gels, GeneScan 500 ROX size standard (Applied Biosystems) was used with ABI, and 400- or 600-bp size standards were used with CEQ depending on the size of the polymerase chain reaction (PCR) fragments. Allele sizes were determined by comparing migration distance to that of the DNA ladder, or by using either GeneMapper Software 4.0 (Applied Biosystems) or the software provided by the CEQ Genetic Analyzer.

Data analyses. Pathotype and microsatellite data were used to compare the diversity of populations of $P$. sojae (i) among states,

Table 1. Collection locations, year, isolate code, source of isolate, multilocus linkage group (MLG), and pathotype written as an octal code of isolates Phytophthora sojae used to evaluate population genetic diversity from one isolate per field in Iowa, Ohio, and South Dakota

\begin{tabular}{|c|c|c|c|c|c|c|}
\hline State & Year & County $^{\mathrm{a}}$ & Isolate code & Baited soil or direct from plant & MLG $^{\mathbf{b}}$ & Pathotype \\
\hline \multirow[t]{17}{*}{ Iowa } & 2001 & Grundy & IA001 & Soil & 5 & 00001 \\
\hline & & Jones & IA002 & Soil & 18 & 00001 \\
\hline & & Johnson & IA003 & Soil & 37 & 33041 \\
\hline & & Greene & IA004 & Soil & 6 & 33001 \\
\hline & & Sioux & IA005 & Soil & 28 & 72000 \\
\hline & & Ringgold & IA006 & Soil & 7 & 73001 \\
\hline & & Lucas & IA007 & Soil & 15 & 00041 \\
\hline & & Adair & IA008 & Soil & 51 & 10001 \\
\hline & 2008 & Monroe & IA051 & Plant & $\mathbf{A}$ & 72201 \\
\hline & & Story & IA091 & Plant & 47 & 72001 \\
\hline & & $\mathrm{n} / \mathrm{d}$ & IA101 & Plant & 42 & 22001 \\
\hline & & Polk & IA111 & Plant & 50 & 00001 \\
\hline & & $\mathrm{n} / \mathrm{d}$ & IA121 & Plant & 29 & 22001 \\
\hline & & Monroe & IA 141 & Plant & $\mathbf{A}$ & 72001 \\
\hline & & Monroe & IA191 & Plant & 44 & 72001 \\
\hline & & Marshal & IA 231 & Soil & 14 & nd \\
\hline & 2009 & Story & IA011 & Plant & 60 & 72001 \\
\hline \multirow[t]{25}{*}{ Ohio } & 1999 & Hancock & OH001 & Soil & 63 & 36573 \\
\hline & & Ottawa & OH002 & Soil & 64 & 36571 \\
\hline & & Defiance & $\mathrm{OH} 003$ & Soil & 4 & 04571 \\
\hline & & Paulding & OH004 & Soil & 49 & 22001 \\
\hline & & Hardin & OH005 & Soil & 53 & 12000 \\
\hline & & Hancock & OH006 & Soil & 62 & 31001 \\
\hline & & Crawford & OH007 & Soil & 23 & 12000 \\
\hline & & Crawford & OH008 & Soil & 24 & 14121 \\
\hline & 2000 & Sandusky & OHS01 & Soil & 32 & 14001 \\
\hline & & Wood & OHW01 & Soil & 17 & 62001 \\
\hline & & Ashland & OHA01 & Plant & 9 & 46221 \\
\hline & 2003 & Clinton & OH009 & Soil & 19 & 04121 \\
\hline & & Franklin & OH010 & Plant & 65 & 36101 \\
\hline & & Fulton & OH012 & Plant & 68 & 36001 \\
\hline & & Sandusky & $\mathrm{OH} 013$ & Plant & 66 & 10343 \\
\hline & & Ashland & $\mathrm{OH} 015$ & Plant & 33 & 76001 \\
\hline & & Wayne & OH016 & Plant & 43 & 76573 \\
\hline & & Wood & OH019 & Plant & 40 & 36573 \\
\hline & 2004 & Defiance & $\mathrm{OH} 020$ & Soil & 11 & 36021 \\
\hline & & Holmes & OH021 & Plant & 61 & 36000 \\
\hline & & Miami & OH023 & Plant & 41 & 36061 \\
\hline & & Wood & OH024 & Soil & 34 & 00021 \\
\hline & & Wood & OH026 & Plant & 69 & avirulent \\
\hline & & Wayne & $\mathrm{OH} 027$ & Plant & 67 & 04100 \\
\hline & & & & & $(\mathrm{con}$ & n next page \\
\hline
\end{tabular}

a County where field is located; $\mathrm{n} / \mathrm{d}$ indicates no data.

b MLG was determined with 21 microsatellite markers and the same MLG are shown in bold. Assignments were made using GenAlEx 6.5 (Peakall and Smouse 2012).

c Pathotype was determined in 15 differentials inoculated with an isolate of $P$. sojae. The octal code was determined with HaGiS, in which 0 indicates an incompatible reaction, and 1 indicates a compatible reaction on the differentials following inoculation. Octal digits were assigned as follows: $000=0,100=1$, $010=2,001=4,110=3,101=5,011=6$, and $111=7$. (Herrmann et al. 1999). The first digit is the response to Rps $1 \mathrm{a}, R p s 1 \mathrm{~b}$, and Rps $1 \mathrm{c}$; the second digit to $R p s 1 \mathrm{~d}, R p s 1 \mathrm{k}$, and Rps2; the third digit to Rps3a, Rps3b, and Rps3c; the fourth digit to Rps4, Rps5, and Rps6; and the fifth digit to Rps7 and Rps8. 
(ii) within fields, and (iii) recovered from individual plants. For comparisons $\mathrm{i}$ and ii, the 21 SSR were used, and for iii only the 8 SSR from capillary electrophoresis were analyzed.

The response of each soybean differential with the respective Rps gene interacting with $P$. sojae was considered as a single locus, so that the virulence formula of the pathogen was named using a binary system, with each of the 14 interactions having one of two possible outcomes: compatible $(=1)$ or incompatible $(=0)$ using the HaGiS Spreadsheet program (Herrmann et al. 1999). Both octal code and Shannon index for pathotype diversity were also calculated using the HaGiS program.

For each isolate, different-sized bands on gels or eletropherogram peaks (fragment sizes) resulting from microsatellite markers were considered to be different alleles. The presence of one allele per locus was treated as a homozygote, while two alleles indicated a heterozygote, and absence of a band or no amplification was treated as missing data. Genetic diversity was assessed as the number of SSR alleles per locus (observed heterozygosity), expected heterozygosity was calculated on a single locus basis (analogous to Nei's gene diversity; Nei 1973), HWE was calculated for each locus, and fixation index (probability that two alleles carried by one individual will be the same) was calculated using population genetic software GenAlEx 6.5 (Peakall and Smouse 2012). Genotypic diversity $(G)$ was calculated as the number of multilocus genotypes (MLG). In order to compare indexes using population of different sizes, $G$ was scaled by the expected number of genotypes for the smallest population size minus one (Grünwald et al. 2003), with rarefaction curves using Rarefaction Program, version 1.3, from Steven M. Holland (http://strata.uga.edu/software/index.html). In addition, we calculated the Simpson's evenness statistic and the Pareto distribution index in GenAlEx, as recommended for organisms with clonality (Arnaud-Haond et al. 2007).

The genetic structure of the $P$. sojae population was analyzed with the analysis of molecular variance (Excoffier et al. 1992). The null hypothesis of a lack of significant differences between states and fields was tested in GenAlEx 6.5 (Peakall and Smouse 2012) using 999 permutations to assess the variance of significant components. Pairwise comparisons of genetic differentiation using genotypic and binary distance among the states and fields were assessed using Weir and Cockerham's $\theta_{\text {ST }}$ (Weir and Cockerham 1984), which is comparable with Wright's $F_{\mathrm{ST}}$. To visualize the population structure of $P$. sojae at the state and field levels, principle coordinate analysis was done using the same software on pairwise genetic distances between all genotypes.

Arlequin 3.5 (Excoffier and Lischer 2010) was used to calculate allele frequencies at each location using the data from 21 microsatellite loci. The two clones were removed from the dataset prior to analysis. To test for differentiation between $P$. sojae populations, pairwise $F_{\mathrm{ST}}$ values were estimated and significance was tested with 1,000 permutations. We also analyzed population structure by using the a priori based clustering program Structure (Falush et al. 2003; Pritchard et al. 2000). Structure uses a Markov-Chain Monte Carlo method in a Bayesian framework to determine the most likely number of populations $(K)$ in a given data set. We performed four different

Table 1. (continued from preceding page)

\begin{tabular}{|c|c|c|c|c|c|c|}
\hline State & Year & County ${ }^{a}$ & Isolate code & Baited soil or direct from plant & MLG $^{\mathbf{b}}$ & Pathotype $^{c}$ \\
\hline & 2005 & Butler & OH028 & Soil & 12 & 26001 \\
\hline & & Delaware & OH030 & Plant & 20 & 00171 \\
\hline & & Hardin & OH031 & Soil & 13 & 72000 \\
\hline & & Wood & $\mathrm{OH} 034$ & Plant & 21 & 34021 \\
\hline & & Summit & $\mathrm{OH} 035$ & Plant & 25 & nd \\
\hline & & Paulding & OH036 & Plant & 3 & 76031 \\
\hline & & Fairfield & OH037 & Plant & 48 & 00100 \\
\hline & 2009 & Miami & OH92PD1 & Plant & 36 & 32771 \\
\hline & & Miami & OH92DF125 & Plant & $\mathbf{B}$ & 00100 \\
\hline & & Miami & OH92DF25 & Plant & $\mathbf{B}$ & 76001 \\
\hline & & Miami & OH92DF32 & Plant & 57 & 76561 \\
\hline & & Miami & OH02BV2 & Plant & 31 & 76101 \\
\hline \multirow[t]{20}{*}{ South Dakota } & 2002 & Lake & SD001 & Plant & 54 & 46163 \\
\hline & & Lincoln & SD002 & Plant & 38 & 32001 \\
\hline & & Clark & SD003 & Plant & 26 & 56570 \\
\hline & & Kingsbury & SD004 & Plant & 27 & 00001 \\
\hline & & Douglas & SD005 & Plant & 46 & 00001 \\
\hline & 2003 & Clay & SD006 & Plant & 35 & 76021 \\
\hline & & Bon Homme & SD007 & Plant & 2 & 26521 \\
\hline & & Deuel & SD008 & Plant & 10 & 56171 \\
\hline & & Grant & SD009 & Plant & 22 & 55001 \\
\hline & & Roberts & SD010 & Plant & 8 & 12200 \\
\hline & & Day & SD011 & Plant & 30 & 10000 \\
\hline & & Sprink & SD012 & Plant & 56 & 10103 \\
\hline & & Minnehaha & SD013 & Plant & 45 & 75120 \\
\hline & 2004 & Brown & SD014 & Plant & 1 & 72551 \\
\hline & & Turner & SD015 & Plant & 16 & 11000 \\
\hline & & Codington & SD016 & Plant & 52 & 50021 \\
\hline & & Brookings & SD017 & Plant & 39 & 10000 \\
\hline & & Miner & SD018 & Plant & 58 & 00001 \\
\hline & & Beadle & SD019 & Plant & 55 & 54151 \\
\hline & & Sanborn & SD020 & Plant & 38 & 04000 \\
\hline \multirow[t]{5}{*}{ Standards } & & Unknown & $\mathrm{R} 02$ & $\ldots$ & $\ldots$ & 20001 \\
\hline & & Unknown & R07 & $\ldots$ & $\ldots$ & 14571 \\
\hline & & Unknown & R14 & $\ldots$ & $\ldots$ & 40001 \\
\hline & & Unknown & R17 & $\begin{array}{l}\cdots \\
\cdots\end{array}$ & $\cdots$ & 21771 \\
\hline & & Unknown & R25 & $\ldots$ & $\ldots$ & 72001 \\
\hline
\end{tabular}


analyses: (i) among all fields ( $K=1$ to 6 ), (ii) among Iowa and South Dakota ( $K=1$ to 4 ), (iii) among Ohio $(K=1$ to 4 ), and (iv) within populations. All runs used default parameters with 500,000 replications as burn-in, followed by $10^{6}$ further replications of the data; each individual run at a given $K$ value was repeated three times. The most likely number of populations was determined by the $\Delta K$ method proposed by Evanno et al. (2005) in the program StructureHarvester (Earl and von Holdt 2012). To further assess clustering, we compared membership proportion among clusters, which measures what proportion of the predefined population identifies with the clusters determined by Structure. We evaluated outcrossing within these populations using the program Colony (Jones and Wang 2010). Colony uses a maximum-likelihood approach to estimate sibship in multilocus genotype data.

\section{Results}

Pathotype and genotype diversity for all $P$. sojae isolates. All but one isolate had a susceptible interaction on the Williams (universal susceptible) and none of the Rps-gene differentials conferred resistance to all isolates of $P$. sojae. Each of the $21 \mathrm{SSR}$ primer pairs used in this study amplified one locus for all of the isolates in this study. For each of the 21 loci, there were 2 to 14 alleles identified: 7 to 14 alleles with six primer pairs; 2 alleles with nine primer pairs; and the remaining 6 primer pairs with 3 or 4 alleles. In total, 99 alleles were scored with the 21 SSR, with an average of 4.7 alleles per locus for this collection of isolates.
Pathotype and genotypic diversity within and among populations of $\boldsymbol{P}$. sojae from Iowa, Ohio, and South Dakota. One isolate each from 17, 36, and 19 locations in Iowa, Ohio, and South Dakota, respectively, was used for this analysis (Table 1; Fig. 1). Isolates were quite different for both pathotype and molecular diversity. The $P$. sojae isolates collected in Ohio had greater virulence complexity and pathotype diversity, as measured by the total number of differentials that did not confer resistance to each isolate and the Shannon Diversity index, followed by South Dakota and Iowa (Fig. 2A;

Table 2. Comparison of the pathotype diversity among single isolates of Phytophthora sojae collected from individual fields in Iowa, Ohio, and South Dakota

\begin{tabular}{lcccc}
\hline Location & $\begin{array}{c}\text { Number } \\
\text { of fields }\end{array}$ & $\begin{array}{c}\text { Number of } \\
\text { pathotypes }\end{array}$ & $\begin{array}{c}\text { Mean } \\
\text { Complexity }\end{array}$ & $\begin{array}{c}\text { Shannon } \\
\text { diversity index }\end{array}$ \\
\hline Iowa & 17 & 10 & 3.7 & 2.15 \\
Ohio & 33 & 30 & 5.7 & 3.37 \\
South Dakota & 20 & 17 & 4.6 & 2.76 \\
\hline
\end{tabular}

a Mean complexity is based on the number of the Rps gene differentials that developed a scorable lesion following inoculation with an isolate of Phytophthora sojae.

b Shannon diversity index was calculated with the HaGiS spreadsheet program (Herrmann et al. 1999).

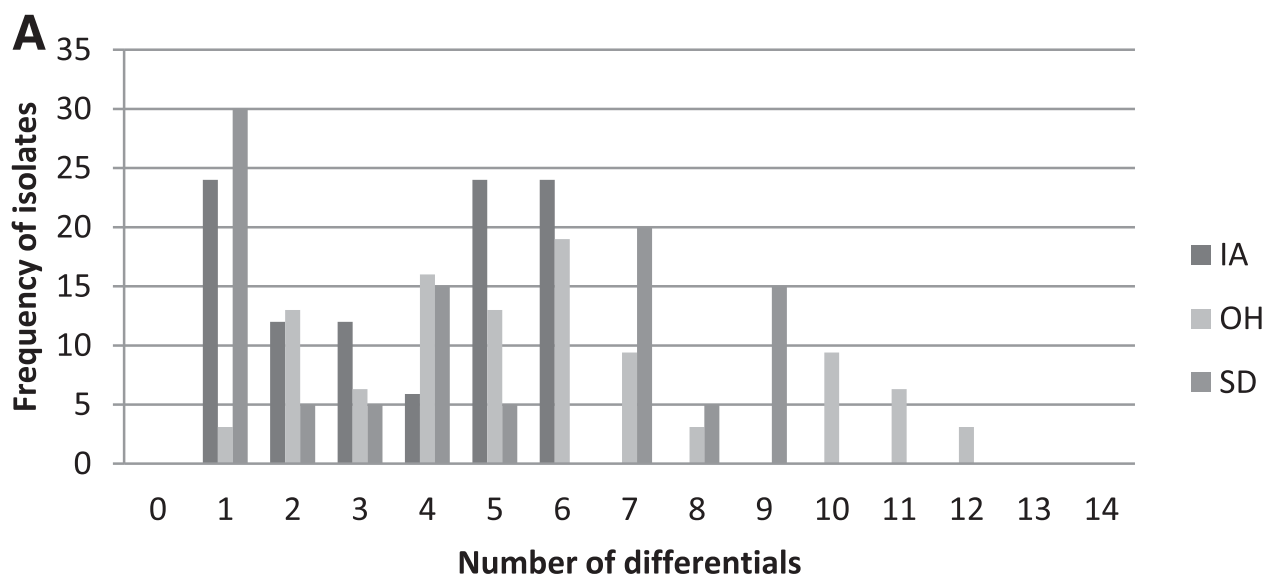

B

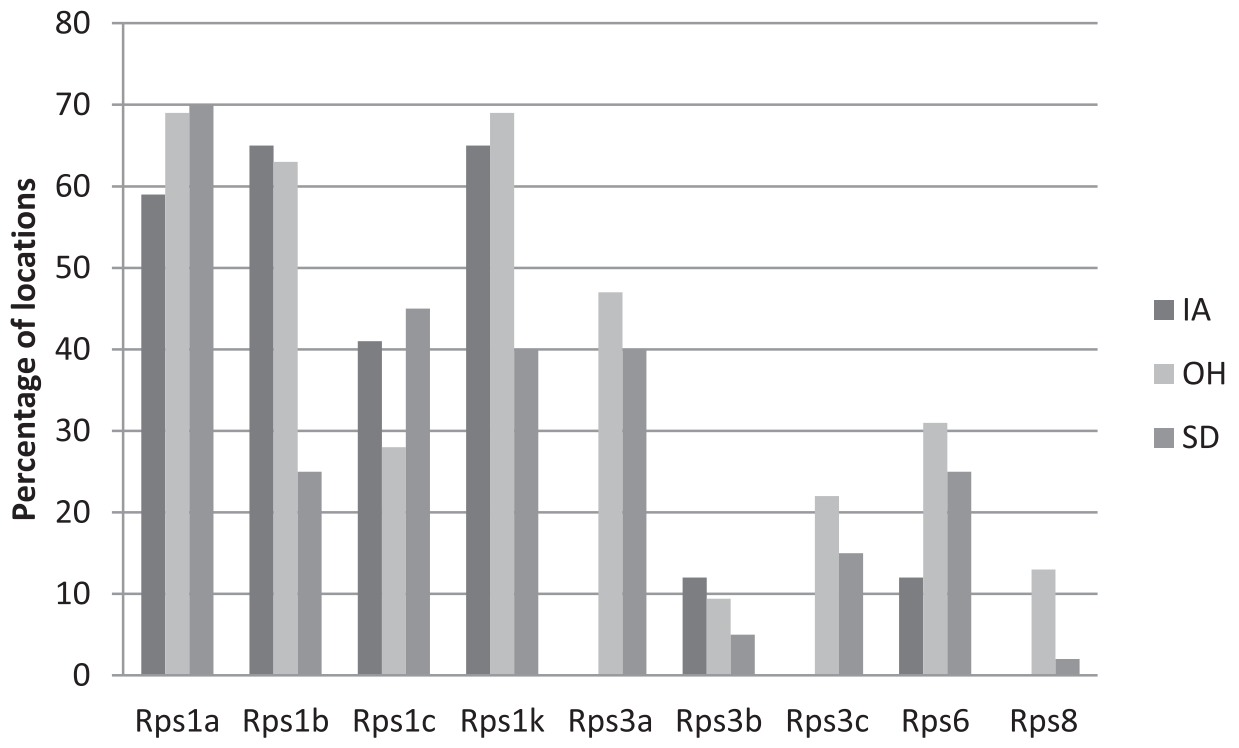

Fig. 2. Comparison of $\mathbf{A}$, virulence complexity as the number of isolates that can cause disease on the different numbers of differentials and $\mathbf{B}$, the percentage of locations where the Rps gene did not confer resistance as a measure of effectiveness among 17, 32, and 20 populations of Phytophthora sojae from lowa, Ohio, and South Dakota, respectively. 
Tables 1 and 2). For the isolates collected in Iowa, the most common pathotype was virulence to Rps7 (octal code 0001), also known as race 1 , followed by those with virulence to $R p s 1 \mathrm{a}, R p s 1 \mathrm{~b}, R p s 1 \mathrm{c}$, $R p s 1 \mathrm{k}$, and Rps7 (72001, also known as race 25). The most commonly deployed $R$ genes (Rps $1 \mathrm{a}, R p s 1 \mathrm{~b}$, and $R p s 1 \mathrm{k}$ ) did not confer resistance to isolates from more than $50 \%$ of the locations in both Iowa and Ohio (Fig. 2B). Although differentials with Rps3a or Rps 8 were resistant to the 17 P. sojae isolates collected from fields in Iowa, they did not confer resistance to all isolates collected in Ohio or South Dakota. The differentials with Rps $1 \mathrm{c}, \operatorname{Rps} 3 \mathrm{a}, \operatorname{Rps} 6$, and $R p s 8$ were susceptible following inoculation with isolates from $27,45,30$, and $12 \%$, respectively, of the locations in Ohio. South Dakota had a similar pattern of distribution for susceptible responses across the differentials but at lower frequencies (Fig. 2B). The Shannon diversity index and the mean complexity, which indicates the number of differentials for which each isolate had a susceptible or compatible response, was higher for Ohio, followed by South Dakota and Iowa (Table 2).

All 21 microsatellite markers used to evaluate these populations were polymorphic for $P$. sojae isolates collected in Ohio, while 10 and 1 were monomorphic in the Iowa and South Dakota isolates, respectively (Table 3). There were 2, 4, and 1 loci which detected putative heterozygotes within Iowa, Ohio, and South Dakota populations, respectively, with microsatellite loci PS01, PS05, PS12, PS20, and PS24 (Table 3). All of the loci deviated significantly from HWE in the comparison across fields, which was expected for this homothallic Phytophthora sp. because most loci were homozygous.

When each population was compared, there was significant genetic differentiation because $F_{\mathrm{ST}}$ values were all less than 0.2 (Table 4). This suggests that $P$. sojae isolates in the states of Iowa, Ohio, and South Dakota are not a single population but are composed of subpopulations with highly restricted gene flow among them. Analysis from the program Structure largely concurred with $F_{\mathrm{ST}}$, with the most likely number of populations $K=2$ when samples from all three states were included (Fig. 3A; Supplementary Table S1 for $\Delta K$ tests), grouping Ohio separately from Iowa and South Dakota. Proportion of membership was high in all inferred clusters, except for Ohio, which had 26\% membership to the Iowa + South Dakota cluster, possibly indicative of subclustering not readily apparent when highly divergent data sets are analyzed together in Structure (Kalinowski 2011). Additional analyses were performed with respect to the $K=2$ inferred clusters (Iowa + South Dakota and Ohio). Structure found significant divergence among neighboring states Iowa and South Dakota $(K=2)$, placing these populations into separate clusters, each with a high membership in proportion to its inferred cluster (Iowa: 98\% and South Dakota: 93\%; Fig. 3B). Within Ohio, $K=3$, with a similar proportion of membership to putative subclusters (Fig. 3C, cluster 1: 31\%, cluster 2: 37\%, and cluster 3: 32\%).

Pathotype and genotypic diversity within individual fields. Among the $P$. sojae isolates recovered within fields, 128 were used to compare pathotype and 107 to compare genetic structure from five, six, and one fields in Iowa, Ohio, and Missouri; respectively. Complete pathotype data were recorded for 128 isolates recovered from these fields, and the number of pathotypes detected per field ranged from 1 to 21 (Table 5). In addition, the mean complexity of these isolates recovered from these fields and the number of differentials (Rps genes) that had a susceptible response following inoculation ranged from 1 (only one $R p s$ gene, former $P$. sojae race 1) in Iowa to 7.2 for isolates from a field in Ohio (Table 5). The number of pathotypes of isolates recovered from plants collected from fields in Iowa was one to three per field, in contrast to isolates from fields in Ohio and Missouri, where the number of pathotypes was almost equal to the total number of isolates recovered. The Shannon Diversity index (Herrmann et al. 1999), which measures the relative differences in pathotype among the isolates, ranged from 1.61 to 2.48 for the fields in Ohio and was 3.01 for one field in Delta, MO, whereas all of the fields in Iowa were less than 1.0.

Table 4. $F_{\mathrm{ST}}$ estimates above the diagonal and significance below the diagonal of population differentiation between pairs of populations of Phytophthora sojae sampled from soybean fields in Iowa, Ohio, and South Dakota ${ }^{\mathrm{a}}$

\begin{tabular}{lccc}
\hline Population & Iowa & Ohio & South Dakota \\
\hline Iowa & $\ldots$ & 0.1722 & 0.1991 \\
Ohio & 0.0003 & $\ldots$ & 0.1049 \\
South Dakota & 0.0003 & 0.0003 & $\ldots$ \\
\hline
\end{tabular}

a Bonferroni $P$ values in italics.

Table 3. Analysis of the microsatellite loci which were polymorphic or monomorphic (M) used to assess multilocus genotype among isolates of Phytophthora sojae for observed $\left(\mathrm{H}_{\mathrm{O}}\right)$ and expected $\left(\mathrm{H}_{\mathrm{E}}\right)$ heterozygosity collected in Iowa, Ohio, and South Dakota ${ }^{\mathrm{a}}$

\begin{tabular}{|c|c|c|c|c|c|c|c|c|c|c|c|c|c|}
\hline \multirow[b]{2}{*}{ Locus } & \multirow[b]{2}{*}{ Band $^{b}$} & \multicolumn{4}{|c|}{ Iowa (17) } & \multicolumn{4}{|c|}{ Ohio (36) } & \multicolumn{4}{|c|}{ South Dakota (20) } \\
\hline & & $\bar{N}$ & Alleles & $\mathbf{H}_{\mathrm{O}}$ & $\mathbf{H}_{\mathrm{E}}$ & $\bar{N}$ & Alleles & $\mathbf{H}_{\mathrm{O}}$ & $\mathbf{H}_{\mathbf{E}}$ & $\bar{N}$ & Alleles & $\mathbf{H}_{\mathrm{O}}$ & $\mathbf{H}_{\mathrm{E}}$ \\
\hline PS01 (12) & $203-443$ & 17 & 5 & 0 & 0.7558 & 35 & 9 & 0.02857 & 0.75901 & 18 & 5 & 0 & $\overline{0.6921}$ \\
\hline PS05 (8) & $263-339$ & 17 & 3 & 0 & 0.5062 & 33 & 5 & 0.06061 & 0.68345 & 19 & 6 & 0 & 0.7397 \\
\hline PS06 & 190,214 & 17 & 1 & M & $\mathrm{nt}$ & 36 & 2 & 0 & 0.31768 & 20 & 2 & 0 & 0.0974 \\
\hline PS10 & $191-251$ & 17 & 3 & 0 & 0.5419 & 36 & 7 & 0 & 0.77934 & 20 & 4 & 0 & 0.6615 \\
\hline PS12 & $251-310$ & 17 & 2 & 0.05882 & 0.5080 & 35 & 4 & 0 & 0.64099 & 19 & 4 & 0 & 0.5121 \\
\hline PS16 & $395-470$ & 17 & 2 & 0 & 0.4706 & 28 & 3 & 0 & 0.61299 & 18 & 3 & 0 & 0.5270 \\
\hline PS17 & 204,213 & 16 & 1 & M & nt & 35 & 2 & 0 & 0.49689 & 20 & 2 & 0 & 0.0974 \\
\hline PS18 & $175-185$ & 16 & 1 & M & nt & 35 & 3 & 0 & 0.42899 & 20 & 1 & M & $\mathrm{nt}$ \\
\hline PS19 & 244,258 & 17 & 1 & M & $\mathrm{nt}$ & 35 & 2 & 0 & 0.20538 & 20 & 2 & 0 & 0.0974 \\
\hline PS 20 & 154,188 & 15 & 2 & 0 & 0.2391 & 36 & 2 & 0.02778 & 0.44092 & 20 & 2 & 0 & 0.0974 \\
\hline PS24 & $236-262$ & 17 & 2 & 0.05882 & 0.2585 & 36 & 4 & 0.11111 & 0.58725 & 19 & 2 & 0.1579 & 0.4225 \\
\hline PS25 & 366,370 & 17 & 1 & M & $\mathrm{nt}$ & 35 & 2 & 0 & 0.49689 & 20 & 2 & 0 & 0.4308 \\
\hline PS27 & $287-329$ & 16 & 1 & M & nt & 35 & 3 & 0 & 0.64265 & 20 & 2 & 0 & 0.1846 \\
\hline PS29 & $249-270$ & 17 & 2 & 0 & 0.4706 & 36 & 2 & 0 & 0.50078 & 18 & 3 & 0 & 0.4127 \\
\hline PS30 & $264-336$ & 17 & 2 & 0 & 0.2995 & 36 & 3 & 0 & 0.45853 & 20 & 3 & 0 & 0.1897 \\
\hline PS33 & $250-266$ & 16 & 2 & 0 & 0.5343 & 27 & 5 & 0 & 0.60098 & 19 & 3 & 0 & 0.4211 \\
\hline PS36 & $189-213$ & 17 & 1 & M & nt & 35 & 3 & 0 & 0.29648 & 20 & 1 & M & nt \\
\hline PS37 & 215,221 & 17 & 1 & M & nt & 35 & 2 & 0 & 0.28820 & 20 & 2 & 0 & 0.4667 \\
\hline PS38 & 245,269 & 17 & 1 & M & $\mathrm{nt}$ & 34 & 2 & 0 & 0.50571 & 20 & 2 & 0 & 0.1846 \\
\hline PS64 & 304,310 & 16 & 2 & 0 & 0.22581 & 35 & 2 & 0 & 0.49689 & 20 & 2 & 0 & 0.5077 \\
\hline PS68 & 456,472 & 16 & 1 & M & $\mathrm{nt}$ & 35 & 2 & 0 & 0.35776 & 20 & 2 & 0 & 0.3846 \\
\hline
\end{tabular}

${ }^{a} N$ indicates the number of isolates where the simple-sequence repeat was amplified and Alleles indicates number of alleles; $\mathrm{nt}=\mathrm{not}$ tested.

b Band sizes are separated by a dash (-) when more than one band size was found in the collection and, where only two alleles were found, they are separated by a comma (,). 
There were 102 MLG identified among the 107 isolates (Table 4) when 3 or more isolates from each field were compared. Four MLG were identified twice and each came from the same field, one each in field Mont-9 in Ohio and IA_1005 in Iowa and two in one field (IA_1019) in Iowa; more importantly, no clone was found in more than one field location within or outside of a region (Table 6). As expected for this homothallic Phytophthora sp., there were very few loci identified that were heterozygous (Table 6). Those loci that were identified

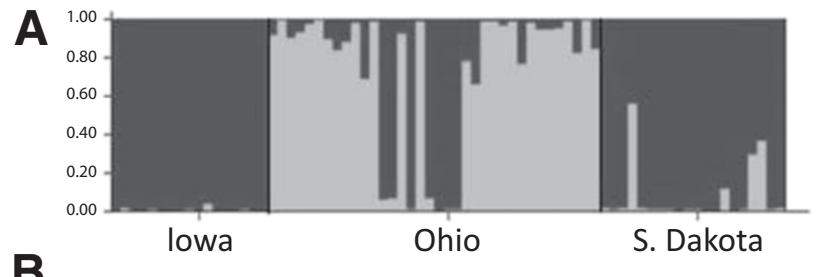

$\mathbf{B}$

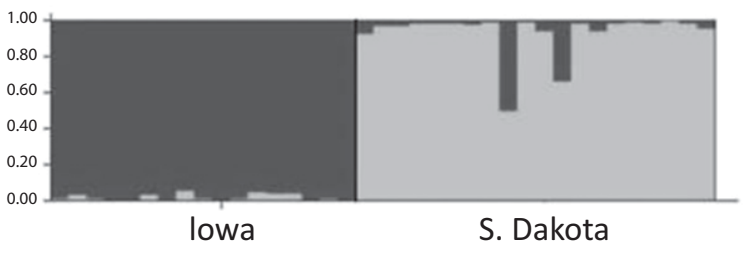

C

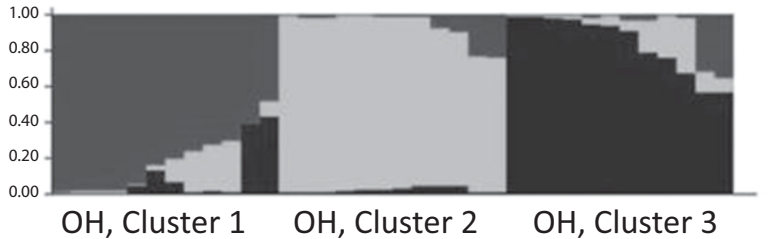

D

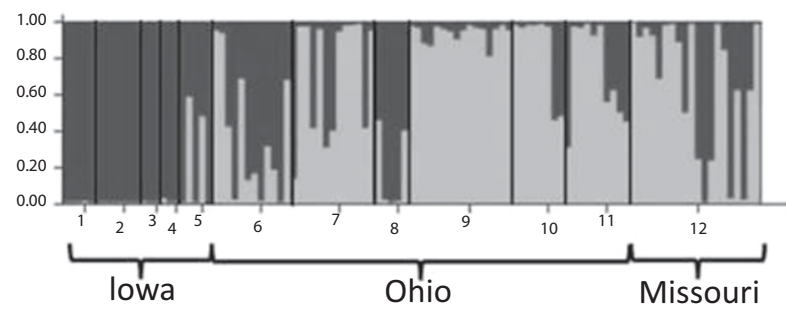

Fig. 3. Membership proportions of populations of Phytophthora sojae to clusters determined by Structure. A, Among all populations of isolates collected from 17, 33, and 20 fields in lowa, Ohio and South Dakota, respectively; B, among lowa and South Dakota; and C, within Ohio. D, Comparison of fields with multiple isolates per field in lowa and Ohio and one field in Missouri. Dark gray = cluster 1, light gray = cluster 2, and black $=$ cluster 3 . Y-axis represents $Q$, or the inferred ancestry of each individual (i.e., vertical bar) to the putative clusters (A to $C$ ). Note: data in $A$ to C are sorted by $Q$. as heterozygous deviated significantly from HWE (data not shown) because only one or two individuals were heterozygous at the locus. Sibship analysis indicated the presence of full-sibs in several populations represented by as many as three families; however, most individuals were unrelated (Table 6).

Additionally, there was significant genetic structure for populations of $P$. sojae collected from several of the intensively sampled fields, primarily those in Ohio and the one field in Missouri, while populations from fields in Iowa were more similar (Table 7; Fig. 4B). $F_{\text {ST }}$ values for comparisons of populations within Iowa were not significantly different from each other but populations with larger numbers of isolates $(\geq 5)$ were significantly different in many of the Ohio locations and the field in Missouri (Table 7). The low number of isolates representing populations may be influencing these results; in fact, other studies have analyzed data with more than 10 isolates per field (Dunn et al. 2010) which, in part, is why we have used the Bonferroni corrected $P$ values (Peakall and Smouse 2012). In spite of some locations with small samples sizes, there were some interesting trends. For example, in Ohio, comparisons of fields which are close geographically were not significantly different (Sand to Wood and Mont-9 and Mont-10 to Mont-11) but pairwise comparisons of fields that are in different regions were significantly different (Table 7). Pairwise comparisons of the field in Missouri were also significant for two of five fields in Iowa and three of six in Ohio. This suggests that gene flow may be occurring among neighboring fields but not across regions. In the principle coordinate analysis, many of the Iowa fields clustered in one quadrant whereas, in most cases, for the fields in Ohio and the field in Missouri, they were placed into two quadrants (Fig. 4).

Structure analyses again confirmed the pairwise comparisons in the within-field data set, $K=2$ (Fig. 3D), with cluster 1 largely consisting of Iowa samples and cluster 2 consisting mostly of Ohio and Missouri samples. Although membership to cluster 1 of Iowa samples was very high (average $94 \%$ among five populations), membership differed among populations from Ohio. For example, whereas most of the Ohio populations had a higher membership to cluster 2, populations 6 and 8 had a higher proportion of membership to cluster 1 (62 and $82 \%$, respectively).

Genetic diversity among isolates of $P$. sojae recovered within a plant. Multiple isolates of $P$. sojae ( $n=52$ isolates) were recovered from 17 plants from eight commercial soybean fields in Iowa, following the criterion of a minimum of two isolates recovered per single plant. Using only eight SSR, more than one MLG was detected among the isolates recovered from eight of the plants ( $n=30$ isolates), and more than one pathotype was detected in isolates recovered from two of the plants ( $n=11$ isolates). Therefore, $47 \%$ of the plants from which multiple isolates were recovered yielded two or three MLG, while $12 \%$ yielded two pathotypes.

One to a maximum of eight SSR loci differed in isolates recovered from a single plant (Table 8). Out of the three isolates recovered from a plant (IA2001-2), three MLG were detected which differed in seven

Table 5. Comparison of within-field pathotype diversity of Phytophthora sojae collected from fields in Iowa, Ohio, and Missouri in which each isolate was recovered from a separate symptomatic soybean plant

\begin{tabular}{llcccc}
\hline State & \multicolumn{1}{c}{ Field } & Number of isolates & Number of pathotypes & Mean complexity & Shannon diversity index $^{\mathbf{a}}$ \\
\hline Iowa & IA_1005 & 11 & 3 & 4.9 & 0.83 \\
& IA_1019 & 9 & 1 & 5.0 & 0.0 (clonal) \\
& IA_1012 & 17 & 2 & 3.2 & 0.55 \\
& IA_1031 & 5 & 1 & 3.8 & 0.0 (clonal) \\
Ohio & IA_2001 & 5 & 2 & 7.2 & 0.67 \\
& OH-Ashland & 5 & 11 & 6.5 & 2.37 \\
& Mont-9 & 12 & 7 & 4.6 & 1.91 \\
& Mont-10 & 8 & 10 & 6.8 & 2.3 \\
& Mont-11 & 10 & 12 & 5.7 & 2.48 \\
& Ohio-Wood & 12 & 9 & 5.3 & 2.15 \\
& Ohio-Sandusky & 11 & 21 & 6.7 & 3.01 \\
\hline
\end{tabular}

${ }^{a}$ Mean complexity is the average number of differentials on which each isolate can cause disease. 
of the eight loci explored. Conversely, in another plant (IA1009-5), the two isolates of $P$. sojae recovered belonged to two pathotypes but a single MLG (Table 8). Additionally, for the nine isolates of $P$. sojae recovered from one plant (IA_1012-2), two MLG and two pathotypes were detected.

Comparison of the population structure of $P$. sojae with previous reports. Five isolates which were part of the study first reported by Förster et al. (1994) were included in this study. P. sojae isolates R02, R07, R14, R17, and R25 were treated as standards and were previously classified in clonal groups IA, IV, IA, III, and IB, respectively (Förster et al. 1994). Complete genotypic data were obtained for all but R07. Each of these isolates had a unique MLG, which was expected because each of these represented a distinct clonal group. The one exception was for R02 and R14, which are not clonal based on this set of SSR markers whereas they were previously reported as clonal based on the RFLP markers (Förster et al. 1994). In the principle coordinate analysis, $P$. sojae isolates R02 and R25 were quite closely related, similar to the previous findings, while R14 and R17 were genetically distinct (Fig. 4).

\section{Discussion}

The highest concentration of fields planted to soybean in the United States occurs in the North-Central region (USDA-NASS 2014), with some cultivars within a maturity group planted across the entire region (east to west); thus, it is important to understand the genetic structure and diversity of key pathogens, particularly $P$. sojae. Pathotype diversity among $P$. sojae populations has been well documented in many of these states, with a number of studies that have reported virulence to Rps genes that have not been deployed (Abney et al. 1997; Kurle and El Araby 2001), extensive virulence diversity within fields (Dorrance et al. 2003; Malvick and Grunden 2004; Robertson et al. 2009), and increasing complexity among isolates compared with historical surveys (Dorrance et al. 2003; Kaitany et al. 2001). The mechanisms that drive these changes are unknown, as well as whether this increase in complexity will affect future gene deployment.

The pathotype variability was high for $P$. sojae populations that were compared among fields and within isolates from single fields, with exceptions of fields in Iowa. Isolates collected from Ohio, South Dakota, and the one field in Missouri were close to having one unique pathotype for each isolate collected. More importantly, none of the Rps genes or most gene combinations provided control of all populations. Furthermore, this study identified that the mean complexity (the number of Rps genes that each of these isolates has a susceptible interaction with) continues to increase over previous reports (Dorrance et al. 2003; Robertson et al. 2009). The

Table 6. Comparison of number of multilocus genotypes (MLG), number of loci that were polymorphic and heterozygous, and sib analysis of Phytophthora sojae sampled during 2000 to 2010 from 12 different locations in Iowa (IA), Ohio (OH), and Missouri (MO)

\begin{tabular}{|c|c|c|c|c|c|c|c|c|}
\hline State & Field & $N^{\mathrm{a}}$ & $\begin{array}{c}\text { Number of } \\
\text { MLG }^{\mathbf{b}}\end{array}$ & $\begin{array}{c}\text { Number of } \\
\text { polymorphic loci }\end{array}$ & $\underset{\text { locic }^{\text {Number of }}}{\mathrm{H}_{\mathrm{O}}}$ & Polymorphic SSR markers ${ }^{d}$ & $\begin{array}{c}\text { Number of full } \\
\text { sibs }^{\mathrm{e}}\end{array}$ & $\begin{array}{l}\text { Number of } \\
\text { Families }\end{array}$ \\
\hline \multirow[t]{5}{*}{ IA } & IA_1005 & 5 & 4 & 4 & 0 & $1,5,6,10$ & 2 & 1 \\
\hline & IA_1012 & 3 & 3 & 4 & 1 & $4,5,14,16$ & 0 & 0 \\
\hline & IA_1019 & 7 & 4 & 1 & 0 & 2 & 3 & 1 \\
\hline & IA_1031 & 3 & 3 & 2 & 0 & 10,16 & 0 & 0 \\
\hline & IA_2001 & 5 & 5 & 12 & 2 & $\mathbf{1 - 3}, 8-10,12,13, \mathbf{1 5}, 17,19,21$ & 2 & 1 \\
\hline \multirow[t]{6}{*}{$\mathrm{OH}$} & Sandusky & 12 & 12 & 18 & 3 & $\mathbf{1 - 2 , 4 - 1 6 , 1 7 , 1 3 - 1 7 , 1 9 - 2 1}$ & 8 & 4 \\
\hline & Wood & 13 & 13 & 20 & 1 & $\mathbf{1}, 2,4-11-21$ & 8 & 4 \\
\hline & Ashland & 5 & 5 & 14 & 0 & $1,2,5,7,10-14,17-21$ & 2 & 1 \\
\hline & Mont-9 & 16 & 15 & 20 & 6 & $\mathbf{1 , 2}, 3, \mathbf{4}, 5-10, \mathbf{1 1}, 13-16, \mathbf{1 7}, 18-21$ & 7 & 3 \\
\hline & Mont-10 & 8 & 8 & 16 & 2 & $1,2,4-8,10,11,13,14,16,18-21$ & 6 & 2 \\
\hline & Mont-11 & 10 & 10 & 18 & 3 & $\mathbf{1}, 2, \mathbf{4}, 5-11,13,14,16-21$ & 5 & 2 \\
\hline MO & Delta & 20 & 20 & 20 & 1 & $1-7,9,10,11,12-21$ & 14 & 5 \\
\hline
\end{tabular}

${ }^{a}$ Number of isolates.

b MLG based on the alleles identified from 21 microsatellite markers.

c Refers to the number of heterozygous $\left(\mathrm{H}_{\mathrm{O}}\right)$ loci that were identified, with two band sizes for the same marker.

d Microsatellite simple-sequence repeat (SSR) markers that were polymorphic and those that identified a heterozygous individual are in bold.

e Sib analysis.

Table 7. Genetic differentiation of populations of Phytophthora sojae from individual plants collected from fields in Iowa (IA), Ohio (OH), and Missouri (MO)

\begin{tabular}{|c|c|c|c|c|c|c|c|c|c|c|c|c|}
\hline & & \multicolumn{11}{|c|}{$F_{\text {ST }}$ values $^{\text {a }}$} \\
\hline \multicolumn{2}{|c|}{ Locations } & \multicolumn{5}{|c|}{ Iowa } & \multicolumn{6}{|c|}{ Ohio } \\
\hline State & Field $(N)^{\mathbf{b}}$ & IA_1005 & IA_1019 & IA_1012 & IA_1031 & IA_2001 & Sand & Wood & Ash & Mont-9 & Mont-10 & Mont-11 \\
\hline \multirow[t]{5}{*}{ IA } & IA_1005 (5) & 0 & $\ldots$ & $\ldots$ & $\ldots$ & $\ldots$ & $\ldots$ & $\ldots$ & $\ldots$ & $\ldots$ & $\ldots$ & $\ldots$ \\
\hline & IA_1019 (7) & 0.799 & 0 & $\ldots$ & $\ldots$ & $\ldots$ & $\ldots$ & $\ldots$ & $\ldots$ & $\ldots$ & $\ldots$ & $\ldots$ \\
\hline & IA_1012(3) & 0.176 & 0.744 & 0 & $\ldots$ & $\ldots$ & $\ldots$ & $\ldots$ & $\ldots$ & $\ldots$ & $\ldots$ & $\ldots$ \\
\hline & IA_1031 (3) & 0.618 & 0.895 & 0.557 & 0 & $\ldots$ & $\ldots$ & $\ldots$ & $\ldots$ & $\ldots$ & $\ldots$ & $\ldots$ \\
\hline & IA_2001 (5) & 0.178 & 0.597 & 0.120 & 0.415 & 0 & $\ldots$ & $\ldots$ & $\ldots$ & $\ldots$ & $\ldots$ & $\ldots$ \\
\hline \multirow[t]{6}{*}{$\mathrm{OH}$} & Sand (12) & $0.364 * *$ & $0.459 * *$ & 0.268 & 0.295 & $0.291 *$ & 0 & $\ldots$ & $\ldots$ & $\ldots$ & $\ldots$ & $\ldots$ \\
\hline & Wood (13) & $0.364 *$ & $0.422^{*}$ & 0.261 & 0.276 & $0.283^{*}$ & 0.090 & 0 & $\ldots$ & $\ldots$ & $\ldots$ & $\ldots$ \\
\hline & Ash (5) & 0.396 & 0.514 & 0.342 & 0.516 & 0.209 & $0.259 * *$ & $0.241 * *$ & 0 & $\ldots$ & $\ldots$ & $\ldots$ \\
\hline & Mont-9 (16) & $0.468^{* *}$ & $0.489 * *$ & 0.382 & 0.422 & $0.375 * *$ & $0.279 * *$ & $0.204 * *$ & $0.310^{* *}$ & 0 & $\ldots$ & $\ldots$ \\
\hline & Mont-10 (8) & $0.584^{*}$ & $0.708 * *$ & 0.515 & 0.516 & 0.461 & $0.323^{* *}$ & $0.209 * *$ & 0.434 & 0.165 & 0 & $\ldots$ \\
\hline & Mont-11 (10) & $0.452 * *$ & $0.580 * *$ & 0.355 & 0.436 & 0.287 & $0.304 * *$ & $0.210 * *$ & $0.279^{*}$ & 0.084 & 0.135 & 0 \\
\hline MO & Delta (20) & $0.288^{* *}$ & $0.375^{* *}$ & 0.221 & 0.215 & 0.186 & $0.156^{* *}$ & 0.106 & 0.175 & $0.158^{* *}$ & $0.203 *$ & 0.131 \\
\hline
\end{tabular}

${ }^{\text {a }} F_{\mathrm{ST}}$ values were calculated in Arlequin, with distances between populations based on allele frequencies in each population. Values followed by $*$ and $* *$ are significantly different from zero based on Bonferroni corrected values at $P<0.05$ and $P<0.01$, respectively using 1,000 permutations.

${ }^{\mathrm{b}}$ Number in parentheses = number of isolates from each site used in this analysis; only isolates from single plants or baited from single soil samples were used. 
exception to this were five fields in Iowa sampled during this study, in which only one to three pathotypes were identified among three to seven isolates collected directly from diseased plants. These five fields were sampled directly from plants with stem rot symptoms in the field, whereas earlier studies (Meng et al. 1999; Robertson et al. 2009) baited from soil with plants with no rps genes. Rps genes have been widely deployed in soybean cultivars in the United States since the 1960s. Because only those isolates with the matching virulence to the Rps gene present in the soybean cultivars grown in those fields would have been recovered, selection for these pathotypes may have been biased. It is also possible that these populations have only recently gained virulence to these Rps genes, thus creating a bottleneck. Selection of relatively few pathotypes recovered following the deployment of a major $R$ gene has been well studied in other host-pathogen systems (Bousset et al. 2002; Burdon and Roelfs 1985).

Rare outcrossing and clonal evolution were first proposed by Förster et al. (1994) as mechanisms that contribute to genetic change within and among $P$. sojae populations. In earlier studies which used RFLP (Förster et al. 1994) and RAPD (Meng et al. 1999), clonal isolates recovered from different geographic locations were identified. Surprisingly, very few clones (i.e., those isolates which share MLG) were identified in this study, and the two isolates with the same MLG came from the same field. Moreover, principle coordinate analysis indicates that there is clustering of individuals for those recovered from fields in Iowa and South Dakota but not for Ohio. This high level of genotypic diversity and relative low allele frequencies could be evidence of random mating (Milgroom 1996) in the Ohio population and in the one field from Missouri. This may explain, in part, the relatively higher number of pathotypes in these other locations compared with those fields which were sampled in Iowa. In theory, clonality, when combined with strong selection exerted by host cultivars, may increase the frequency of the fittest genotypes (McDonald and Linde 2002a), and this may be what is occurring in the fields in Iowa because these populations may have only recently gained virulence to the $R p s$ genes that were deployed in those specific fields. With the addition of outcrossing within a field or region, the emergence of new virulence combinations as well as increased complexity is expected. Based on the lack of clones and the large number of MLG within and among fields in Ohio, South Dakota and one field in Missouri, outcrossing may be contributing more to genetic diversity, rather than mutation alone. Goyeau et al. (2007) were able to verify clonal reproduction in populations of Puccinia triticina which causes wheat leaf rust, primarily due to a very intensive sampling of isolates from rust pustules on two wheat cultivars with specific $R$ genes. The same or similar genotypes were recovered from each wheat cultivar.

This study, which included isolates of Phytophthora sojae from Iowa, Ohio, Missouri, and South Dakota, detected high overall diversity, higher than expected for a soilborne organism with a homothallic

A

Principal Coordinates (PCOA)

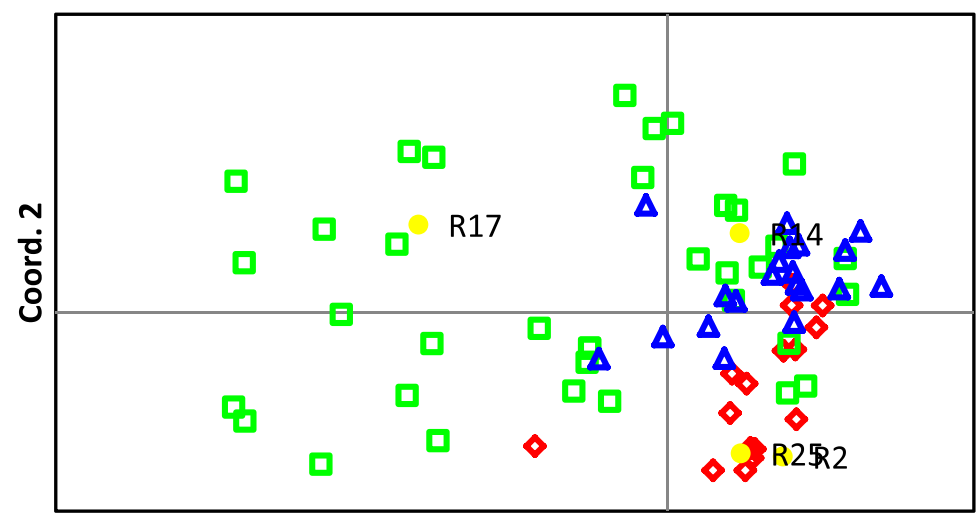

Coord. 1

B

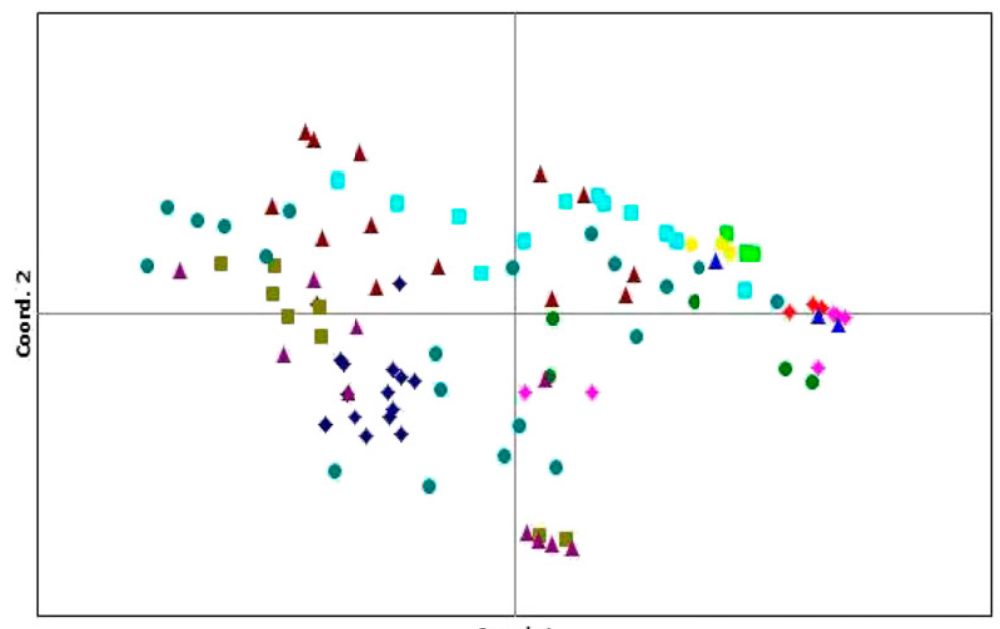

- lowa

口Ohio

$\Delta$ South Dakota

Checks

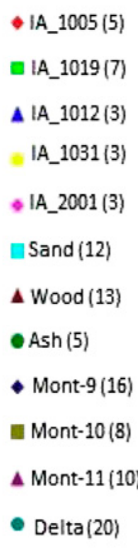

IA_1019 (7)

IA_1012 (3)

IA_1031(3)

IA_2001 (3)

Sand (12)

$\Delta$ Wood (13)

- Ash (5)

- Mont-9 (16)

A Mont-11(10)

- Delta (20)

Fig. 4. Scatter plot of isolates of Phytophthora sojae on principle coordinates 1 and 2 collected from A, a single plant or soil sample per field in lowa, Ohio, and South Dakota and B, a single plant or soil sample from individual fields in lowa, Ohio, and Missouri. 
(selfing) reproductive nature, because few clones were identified. For a homothallic species, this level of diversity is puzzling but not unusual because this is still less than other Phytophthora spp. North American populations of $P$. alni subsp. uniformis, which causes alder decline, exhibited levels of gene diversity similar to heterothallic outcrossing oomycetes (Aguayo et al. 2013). One reason for the level of differentiation among the populations of $P$. sojae in this study is the depth of sampling with the microsatellites. We utilized 21 microsatellite markers which collectively identified more than 90 alleles, which is a much greater depth than the previous studies of population genetics of $P$. sojae (Förster et al. 1994; Meng et al. 1999).

Predictions have been made that there should be almost no heterozygosity in homothallic Phytophthora populations (Goodwin 1997). It is possible that subculturing to purify isolates and culturing for pathotyping and DNA isolation could have promoted selfing of some isolates that underestimated the prevalence of heterozygotes in our populations. Self-fertilization reduces the amount of heterozygosity by one-half in every generation; thus, less than $1 \%$ of the original heterozygosity should remain after only seven generations (Goodwin 1997). This may explain, in part, why so few loci detected were heterozygous when outcrossing may be a means to increase diversity. Different methodology is needed to detect heterozygotes at the time isolates are recovered from plants in the field.

McDonald and Linde (2002a) proposed that there was a medium risk that $P$. sojae is a pathogen capable of overcoming resistance, and proposed two strategies to achieve durable resistance to the pathogen: (i) rotation of major $R$ genes on a regional basis, understanding that virulent mutants that arise in one region will not effectively emigrate to other region due to low gene flow; or (ii) quantitative resistance. The findings from this study further support their proposition that $P$. sojae is a medium-risk pathogen but also raise questions regarding the long-term reliance of major $R$ genes as a disease management strategy. Due to the diversity and increasing complexity, rotation of $R$ genes is probably no longer a viable strategy. This is primarily due to the increasing complexity of the pathotype of $P$. sojae isolates over successive samplings, although a larger, more in-depth survey of pathotypes would be necessary to assess whether this true for the entire North-Central region. Because virulence to many of the $R$ genes is maintained within these populations, identification of new and novel $R$ genes will continue to be of upmost importance. More importantly, strategies such as quantitative resistance that put less selection pressure on the pathogen population should become a higher priority.

Genetic structures of plant pathogen species, including Phytophthora spp., are not always the same in one location compared with another and this can have profound influences on how these diseases are managed at local levels (Dunn et al. 2010). This may be due to specific geographic location, the number of epidemics or infection events that occur each year, local agricultural practices, or the history of introductions of new genotypes into a locality (Barrett et al. 2008; Dunn et al. 2010; Fry et al. 1992). Anderson (1986) had suggested that greater disease incidence of Phytophthora root and stem rot was the result of a greater number of infection events which, in turn, could result in higher levels of diversity within $P$. sojae populations. The findings from this study support this idea and suggest that numerous subpopulations may exist, each with presumably different effectors that may or may not be managed with novel Rps, as with the populations from Missouri that have virulence toward the $R$ gene Rps8. The analysis of multiple isolates per field from Iowa showed that the SSR that were polymorphic were different for each field. Sampling larger numbers of isolates per field within a state or production region is necessary to understand the potential number of subpopulations and overall genetic diversity. This was also the conclusion from a recent study of $P$. capsici, another soilborne pathogen, of isolates representing six continents, 21 countries, 19 U.S. states, and 26 different hosts (Quesada-Ocampo et a. 2011). As outlined by Barrett et al. (2008), the life history of $P$. sojae would predict decreased population size due to its specialized annual host (soybean) and restricted local dispersal.

The number of locations within a region sampled as well as the number of isolates from individual fields may have contributed to some of the outcomes of population genetic analysis. To bait and recover $P$. sojae from soil or plants is not an inconsequential task. However, with the small sample sizes $(<5$ for some locations) for some of the analysis, key findings of moderate levels of diversity among and within these populations are in contrast to previous studies. With a greater number of samples, diversity would be similar or greater but does not decline. This study failed to identify a clone when individual isolates from individual fields were compared as well as from very few clones from fields where disease pressure tends to be high (Ohio, Missouri, and South Dakota). The baiting process with plants that did not contain an Rps gene will not select for more recent pathotypes. However, isolates recovered directly from plants with $R p s 1 \mathrm{c}$ or $R p s 1 \mathrm{k}$

Table 8. Number of isolates $(N)$, multilocus genotypes (MLG), and pathotypes of Phytophthora sojae recovered from lesions on nine soybean plants with characteristic symptoms of Phytophthora root rot collected from five fields in Iowa.

\begin{tabular}{|c|c|c|c|c|c|c|}
\hline \multirow[b]{2}{*}{ Code $^{c}$} & \multirow[b]{2}{*}{$N^{\mathrm{d}}$} & \multicolumn{3}{|c|}{ MLG $^{\mathbf{a}}$} & \multicolumn{2}{|c|}{ Pathotypes $^{\text {b }}$} \\
\hline & & $\mathbf{I}$ & II & III & $\mathbf{I}$ & II \\
\hline IA1005-8 & 3 & $\begin{array}{l}\text { PS12((304), PS20(188), } \\
\text { PS24(252), PS29(270) }\end{array}$ & $\begin{array}{l}\text { PS12(251), PS20(174), } \\
\text { PS24(236), PS29(249) }\end{array}$ & & & \\
\hline IA $1005-9$ & 5 & PS29(174) & PS20(188) & & & \\
\hline IA1012-1 & 4 & PS01(419), PS05(339), PS10(191) & $\begin{array}{l}\text { PS01(419), PS05(3397347), } \\
\text { PS10(191) }\end{array}$ & $\begin{array}{l}\text { PS01(281), PS05(263), } \\
\text { PS10(191/221) }\end{array}$ & & \\
\hline IA1012-2 & 9 & PS05(343) & PS05(339) & & $1 \mathrm{~b}, 1 \mathrm{k}, 7$ & $1 \mathrm{~b}, 1 \mathrm{c}, 1 \mathrm{k}, 7$ \\
\hline IA1012-5 & 2 & PS05(343) & PS04(339) & & & \\
\hline IA1019-1 & 2 & PS24(236) & PS24(252) & & & \\
\hline IA2001-1 & 2 & $\begin{array}{l}\text { PS19(258), PS20(188), PS25(366), } \\
\text { PS27(287), PS30(300), PS36 } \\
(213), \text { PS38(245), PS68/69(456) }\end{array}$ & $\begin{array}{l}\text { PS19(244), PS20(174), PS25(370), } \\
\text { PS27(329), PS30(300/336), PS36 } \\
(189), \text { PS38(269), PS68/69(472) }\end{array}$ & & & \\
\hline IA2001-2 & 3 & $\begin{array}{l}\text { PS06(214), PS18(185), PS19(258), } \\
\text { PS20(188), PS27(287), } \\
\text { PS30(264), PS68/69(472) }\end{array}$ & $\begin{array}{l}\text { PS06(190), PS18(175), PS19(244), } \\
\text { PS20(174), PS27(303), } \\
\text { PS30(280), PS68/69(456) }\end{array}$ & $\begin{array}{l}\text { PS06(214), PS18(185), PS19(258), } \\
\text { PS20(188), PS27(287), PS30(300), } \\
\text { PS68/69(456) }\end{array}$ & & \\
\hline IA $1009-5$ & 2 & & & & $1 \mathrm{a}, 1 \mathrm{c}, 1 \mathrm{k}, 7$ & $1 \mathrm{a}, 1 \mathrm{~b}, 1 \mathrm{c}, 1 \mathrm{k}, 7$ \\
\hline
\end{tabular}


had levels of diversity similar to those that were baited from soils collected in Ohio. In order to accurately predict the longevity of specific Rps genes or novel gene strategies, a more thorough sampling and analysis of populations that examines within-field variation within a geographic region is needed to truly address the nature of outcrossing, migration, and clonal reproduction on the genetic structure of $P$. sojae both regionally and globally.

\section{Acknowledgments}

We thank G. Shannon for contributing the isolates from Missouri to this study, T. Harrington for reviewing an earlier version of the manuscript, V. Silva (Iowa) and L. Zelaya-Molina (Ohio) for technical assistance in these studies, and the OARDC Molecular Cellular Imaging Center for assistance in sequencing. Salaries and research support were provided, in part, by State and Federal Funds appropriated to the OARDC, The Ohio State University, Iowa State University, and South Dakota State University. This project was funded, in part, by Soybean Producers' check-off dollars through the Iowa Soybean Association, Ohio Soybean Council, and United Soybean Board.

\section{Literature Cited}

Abney, T. S., Melgar, J. C., Richards, T. L., Scott, D. H., Grogan, J., and Young, J. 1997. New races of Phytophthora sojae with Rps1-d virulence. Plant Dis. 81: 653-655.

Aguayo, J., Adams, G. C., Halkett, F., Catal, M., Husson, C., Nagy, Z. A., Hansen, E. M., Marcais, B., and Frey, P. 2013. Strong genetic differentiation between North American and European populations of Phytophthora alni subsp. uniformis. Phytopathology 103:190-199.

Anderson, T. R. 1986. Plant losses and yield responses to monoculture of soybean cultivars susceptible, tolerant, and resistant to Phytophthora megasperma f. sp. glycinea. Plant Dis. 70:468-471.

Arnaud-Haond, S., Duarte, C. M., Alberto, F., and Serrao, E. A. 2007. Standardizing methods to address clonality in population studies. Mol. Ecol. 16:5115-5139.

Barrett, L. G., Thrall, P. H., Burdon, J. J., and Linde, C. C. 2008. Life history determines genetic structure and evolution of host-parasite interactions. Trends Ecol. Evol. 23:678-685.

Bousset, L., Hovmøller, M. S., Caffier, V., de Vallavieille-Pope, C., and Østergård, H. 2002. Observed and predicted changes over eight years in frequency of barley powdery mildew avirulent to spring barley in France and Denmark. Plant Pathol. 51:33-44

Burdon, J. J., and Roelfs, A. P. 1985. The effect of sexual and asexual reproduction on the isozyme structure of populations of Puccinia graminis. Phytopathology 75:1068-1073.

Chen, R., and McDonald, B. A. 1995. Sexual reproduction plays a major role in the genetic structure of populations of the fungus Mycosphaerella graminicola. Genetics 142:1119-1127.

Dorrance, A. E., Berry, S. A., Abney, T. S., and Anderson, T. 2008. Isolation, storage, pathotype characterization, and evaluation of resistance for Phytophthora sojae in soybean. Online publication. Plant Health Prog. doi: 10.1094/PHP-2008-0118-01-DG

Dorrance, A. E., and Grünwald, N. 2009. Phytophthora sojae: Diversity among and within populations. Pages 197-212 in: Oomycetes Genetics and Genomics: Diversity, Interactions, and Research Tools. K. Lamour and S. Kamoun, eds. John Wiley and Sons, Inc., Hoboken, NJ.

Dorrance, A. E., Inglis, A. D., Derie, M. L., Brown, C. R., Goodwin, S. B., Fry, W. E., and Deahl, K. L. 1999. Characterization of Phytophthora infestans population in western Washington. Plant Dis. 83:423-428.

Dorrance, A. E., Jia, H., and Abney, T. S. 2004. Evaluation of soybean differentials for their interaction with Phytophthora sojae. Online publication. Plant Health Prog. doi: 10.1094/PHP-2004-0309-01-RS.

Dorrance, A. E., McClure, S. A., and deSilva, A. 2003. Pathogenic diversity of Phytophthora sojae in Ohio soybean fields. Plant Dis. 87:139-146.

Drenth, A., Whisson, S. C., Maclean, D. J., Irwin, J. A. G., Obst, N. R., and Ryley, M. J. 1996. The evolution of races of Phytophthora sojae in Australia. Phytopathology 86:163-169.

Dunn, A. R., Milgroom, M. G., Meitz, J. C., McLeod, A., Fry, W. E., McGrath, M. T., Dillard, H. R., and Smart, C. D. 2010. Population structure and resistance to mefenoxam of Phytophthora capsici in New York State. Plant Dis. 94: 1461-1468.

Earl, D. A., and von Holdt, B. M. 2012. STRUCTURE HARVESTER: A website and program for visualizing STRUCTURE output and implementing the Evanno method. Conserv. Genet. Resour. 4:359-361.

Evanno, G., Reginaut, S., and Goudet, J. 2005. Detecting the number of clusters of individuals using the software STRUCTURE: A simulation study. Mol. Ecol. 14:2611-2620.

Excoffier, L., and Lischer, H. E. L. 2010. Arlequin suite ver. 3.5: A new series of programs to perform population genetic analyses under Linux and Windows. Mol. Ecol. Resour. 10:564-567.

Excoffier, L., Smouse, P. E., and Quattro, J. M. 1992. Analysis of molecular variance inferred from metric distances among DNA haplotypes: Application to human mitochondrial DNA restriction sites. Genetics 131:479-491.
Falush, D., Stephens, M., and Pritchard, J. K. 2003. Inference of population structure using multilocus genotype data: Linked loci and correlated allele frequencies. Genetics 164:1567-1587.

Flor, H. H. 1955. Host-parasite interactions in flax rust-its genetics and other implications. Phytopathology 45:680-685.

Förster, H., Kinscherf, T. G., Leong, S., and Maxwell, D. P. 1989. Restriction fragment length polymorphisms of the mitochondrial DNA of Phytophthora megasperma isolated from soybean, alfalfa, and fruit trees. Can. J. Bot. 67: 529-537.

Förster, H., Tyler, B. M., and Coffey, M. D. 1994. Phytophthora sojae races have arisen by clonal evolution and by rare outcrosses. Mol. Plant-Microbe Interact. 7:780-791.

Fry, W. E., Goodwin, S. B., Matuszak, J. M., Spielman, L. J., Milgroom, M. G., and Drenth, A. 1992. Population genetics and intercontinental migrations of Phytophthora infestans. Annu. Rev. Phytopathol. 30:107-130.

Goodwin, S. B. 1997. The population genetics of Phytophthora. Phytopathology 87:462-473.

Goyeau, H., Halkett, F., Zapater, M. F., Carlier, J., and Lannou, C. 2007. Clonality and host selection in the wheat pathogenic fungus Puccinia triticina. Fungal Genet. Biol. 44:474-83.

Grau, C. R., Dorrance, A. E., Russin, J., and Bond, J. 2004. Fungal diseases. Pages 679-763 in: Soybeans: Improvement, Production, and Uses. H. R. Boerma and J. E. Specht, eds. American Society of Agronomy, Crop Science Society of America, Soil Science Society of America, Inc., Madison, WI.

Grünwald, N. J., Goodwin, S. B., Milgroom, M. G., and Fry, W. E. 2003. Analysis of genotypic diversity data for populations of microorganisms. Phytopathology 93:738-746.

Herrmann, A., Löwer, C. F., and Schachtel, G. A. 1999. A new tool for entry and analysis of virulence data for plant pathogens. Plant Pathol. 48:154-158.

Jones, O., and Wang, J. 2010. COLONY: A program for parentage and sibship inference from multilocus genotype data. Mol. Ecol. Resour. 10:551-555.

Kaitany, R. C., Hart, L. P., and Safir, G. R. 2001. Virulence composition of Phytophthora sojae in Michigan. Plant Dis. 85:1103-1106.

Kalinowski, S. T. 2011. The computer program STRUCTURE does not reliably identify the main genetic clusters within species: Simulations and implications for human population structure. Heredity 106:625-632.

Kurle, J. E., and El Araby, E. M. 2001. Changing composition of Phytophthora sojae races in Minnesota soils. (Abstr.) Phytopathology 91:S51.

Lin, F., Zhao, M., Ping, J., Johnson, A., Zhang, B., Abney, T. S., Hughes, T. J., and Ma, J. 2013. Molecular mapping of two genes for resistance to Phytophthora sojae in a soybean landrace PI 567139B. Theor. Appl. Genet. 126:2177-2185

Malvick, D. K., and Grunden, E. 2004. Traits of soybean-infecting Phytophthora populations from Illinois agricultural fields. Plant Dis. 88:1139-1145.

McDonald, B. A., and Linde, C. 2002a. Pathogen population genetics, evolutionary potential, and durable resistance. Annu. Rev. Phytopathol. 40: 349-379.

McDonald, B. A., and Linde, C. 2002b. The population genetics of plant pathogens and breeding strategies for durable resistance. Euphytica 124:163-180.

Meng, X. Q., Shoemaker, R. C., and Yang, X. B. 1999. Analysis of pathogenicity and genetic variation among Phytophthora sojae isolates using RADP. Mycol. Res. 103:173-178.

Milgroom, M. G. 1996. Recombination and the multilocus structure of fungal populations. Annu. Rev. Phytopathol. 34:457-477.

Nei, M. 1973. Analysis of gene diversity in subdivided populations. Proc. Natl. Acad. Sci. USA 70:3321-3323.

Niu, X. 2004. Assessment of Phytophthora sojae race population and fitness components in Iowa. Master's thesis, Iowa State University, Ames.

Peakall, R., and Smouse, P. E. 2012. GenAlex 6.5: Genetic analysis in Excel. Population genetic software for teaching and research. Bioinformatics 28:2537-2539.

Pritchard, J. K., Stephens, M., and Donnelly, P. 2000. Inference of population structure using multilocus genotype data. Genetics 155:945-959.

Quesada-Ocampo, L. M., Granke, L. L., Mercier, M. R., Olsen, J., and Hausbeck, M. K. 2011. Investigating the genetic structure of Phytophthora capsici populations. Phytopathology 101:1061-1073.

Robertson, A. E., Cianzio, S. R., Cerra, S. M., and Pope, R. O. 2009. Within-field pathogenic diversity of Phytophthora sojae in commercial soybean fields in Iowa. Online publication. Plant Health Prog. doi: 10.1094/PHP-2009-0908-01-RS

Schena, L., Cardle, L., and Cooke, D. 2008. Use of genome sequence data in the design and testing of SSR markers for Phytophthora species. BMC Genomics 9:620.

Schmitthenner, A. F. 1985. Problems and progress in control of Phytophthora roo rot of soybean. Plant Dis. 69:362-368.

Schmitthenner, A. F., and Bhat, R. G. 1994. Useful methods for studying Phytophthora in laboratory. OARDC Spec. Circ. 143:1-10.

Schmitthenner, A. F., Hobe, M., and Bhat, R. G. 1994. Phytophthora sojae races in Ohio over a 10-year interval. Plant Dis. 78:269-276.

Stewart, S., Wickramasinghe, D., Dorrance, A. E., and Robertson, A. E. 2011 Comparison of three microsatellite analysis methods for detecting genetic diversity in Phytophthora sojae (Stramenopila: Oomycete). Biotechnol. Lett. $33: 2217-2223$

Sun, S., Wu, X. L., Zhao, J. M., Wang, Y. C., Tang, Q. H., Yu, D. Y., Gai, J. Y., and Xing, H. 2011. Characterization and mapping of Rps Yu25, a novel resistant gene to Phytophthora sojae. Plant Breed. 130:139-143. 
Tyler, B. M., Tripathy, S., Zhang, X., Dehal, P., Jiang, R. H. Y., Aerts, A., Arredondo, F. D., Baxter, L., Bensasson, D., Beynon, J. L., Chapman, J., Damasceno, C. M. B., Dorrance, A. E., Dou, D., Dickerman, A., Dubchak, I. L., Garbelotto, M., Gijzen, M., Gorgon, S. G., Govers, F., Grunwald, N. J., Huang, W., Ivors, K. L., Jones, R. W., Kamoun, S., Krampis, K., Lamour, K. H., Lee, M., McDonald, W. H., Medina, M., Miejer, H. G. G., Nordber, E. K., Maclean, D. J., Ospina-Giraldo, M. D., Morris, P. F., Phuntumart, V., Putnam, N. H., Rash, S., Rose, J. K. C., Sakihama, Y., Salamov, A. A., Savidor, A., Schuering, C. F., Smith, B. M., Sobral, B. W. S., Terry, A., Torto-Alalibo, T. A., Win, J., Xu, Z., Zhang, H., Grigoriev, I. V., Rokhsar, D. S., and Boore, J. L. 2006. Phytophthora genome sequences uncover evolutionary origins and mechanisms of pathogenesis. Science 313:1261-1266.

USDA-NASS. 2014. United States Department of Agriculture National Agricultural Statistics Service website, http://www.nass.usda.gov/Statistics by Subject/result.php? AC6583D7-1E57-32B6-89EF-37419FD44B15\&sector=CROPS\&group=FIELD\% 20CROPS\&comm=SOYBEANS

Weir, B. S., and Cockerham, C. C. 1984. Estimating F-statistics for the analysis of population structure. Evolution 38:1358-1370.
Whisson, S. C., Drenth, A., Maclean, D. J., and Irwin, J. A. G. 1994. Evidence for outcrossing in Phytophthora sojae and linkage of a DNA marker to two avirulence genes. Curr. Genet. 27:77-82.

White, T. J., Bruns, T., Lee, S., and Taylor, J. 1990. Amplification and direct sequencing of fungal ribosomal RNA genes for phylogenetics. Pages 315-322 in: PCR protocols: A Guide to Methods and Applications. M. A. Innis, D. H. Gelfand, J. J. Sninsky, and T. J. White, eds. Academic Press, Inc., San Diego, CA.

Wrather, J. A., and Koenning, S. R. 2009. Effects of diseases on soybean yields in the United States 1996 to 2007. Online publication. Plant Health Prog. doi: 10.1094/PHP-2009-0401-01-RS

Yang, X. B., Ruff, R. L., Meng, X. Q., and Workneh, F. 1996. Races of Phytophthora sojae in Iowa soybean fields. Plant Dis. 80:1418-1420.

Zelaya-Molina, L. X., Ortega, M. A., and Dorrance, A. E. 2011. Easy and efficient protocol for oomycete DNA extraction suitable for population genetic analysis. Biotechnol. Lett. 33:715-720.

Zhang, J., Xia, C., Duan, C., Sun, S., Wang, X., Wu, X., and Zhu, Z. 2013. Identification and candidate gene analysis of a novel Phytophthora resistance gene Rps10 in a Chinese soybean cultivar. PLoS One 8:e69799. 